\title{
Syntheses, Characterization, Antimicrobial Activity and Extraction Studies of Tetraaza Macrocyclic/Linear Schiff Bases Derived from Benzene-1,4-Dicarboxaldehyde and Their Coordination Compounds
}

\author{
Temitayo Aiyelabola ${ }^{1}$, Johan Jordaan², Daniel Otto ${ }^{2}$, Ezekiel Akinkunmi ${ }^{3}$ \\ ${ }^{1}$ Department of Chemistry, Obafemi Awolowo University, Ile-Ife, Nigeria \\ ${ }^{2}$ Research Focus Area for Chemical Resource Beneficiation, Laboratory for Analytical Services; North-West University, \\ Potchefstroom, South Africa \\ ${ }^{3}$ Department of Pharmaceutics, Obafemi Awolowo University, Ile-Ife, Nigeria \\ Email: taiyelabola@gmail.com, Johan.Jordaan@nwu.ac.za, Daniel.Otto@nwu.ac.za, \\ eoakinmi@oauife.edu.ng, ‘taiyelabola@oauife.edu.ng
}

How to cite this paper: Aiyelabola, T., Jordaan, J., Otto, D. and Akinkunmi, E. (2021) Syntheses, Characterization, Antimicrobial Activity and Extraction Studies of Tetraaza Macrocyclic/Linear Schiff Bases Derived from Benzene-1,4-Dicarboxaldehyde and Their Coordination Compounds. Advances in Biological Chemistry, 11, 79-105. https://doi.org/10.4236/abc.2021.113007

Received: March 6, 2021

Accepted: May 9, 2021

Published: May 12, 2021

Copyright $\odot 2021$ by author(s) and Scientific Research Publishing Inc. This work is licensed under the Creative Commons Attribution International License (CC BY 4.0).

http://creativecommons.org/licenses/by/4.0/

(c) (i) Open Access

\begin{abstract}
Non-template $[2+2]$ condensation of benzene-1,4-dicarboxaldehyde with two diamines: ethane-1,2-diamine and propane-1,2-diamine was carried out to give Ligands 1 and 2 . Additionally, template $[1+2]$ condensation of benzene-1,4-dicarboxaldehyde with ethane-1,2-diamine and propane-1,2-diamine were also carried out to give Ligands 3 and $\mathbf{4}$. These were characterized using ${ }^{1} \mathrm{H}$ and ${ }^{13} \mathrm{C}$ NMR, UV-Vis and infra-red spectroscopy and mass spectrometry. Coordination compounds of each ligand were further synthesized using $\mathrm{Ni}(\mathrm{II})$ and $\mathrm{Cu}(\mathrm{II})$ ions. They were characterized by Uv-vis, infrared spectroscopy, mass spectrometry, magnetic susceptibility and energy dispersion X-ray spectroscopy EDX. The ligands and complexes were further analyzed for their antimicrobial activities and extraction efficiency. The results obtained suggested that tetraaza macrocyclic and linear compounds were obtained for $[2+$ $2]$ and $[1+2]$ condensation reactions respectively. Coordination compounds of the macrocyclic ligand yielded octahedral geometry for $\mathrm{Ni}(\mathrm{II})$ and $\mathrm{Cu}(\mathrm{II})$ complexes of Ligand 1 and square planar geometry for $\mathrm{Ni}(\mathrm{II})$ and $\mathrm{Cu}(\mathrm{II})$ complexes of Ligand 2. On the other hand square planar geometry was proposed for coordination compounds of Ligand 3 and 4 exception for the $\mathrm{Ni}(\mathrm{II})$ complex of Ligand 3. All ligands coordinated to the metal ion in a tetradentate fashion. In some cases chelation enhanced the antimicrobial activity of some of the ligands. The results further showed that Ligands 1-4 effectively
\end{abstract}


extracted cadmium(II). zinc(II) and lead(II) ions in solution.

\section{Keywords}

Component, Formatting, Style, Styling, Insert

\section{Introduction}

Schiff bases are a growing class of compounds with varying chemistry. They have often been in use as chelating agents in coordination chemistry [1] [2] [3] [4]. As a result of the versatility of their donor atoms, they are regarded as privileged ligands [5]. They have also been reported to exhibit a number of important biological activities which include anti-bacterial, -fungal, -diabetic and -tumor [6]-[14].

In the syntheses of these Lewis bases however earlier reports have indicated that reactions of dicarbonyl compounds with diamines may be complicated, resulting in a plausible wide spectrum of products [15] [16]. Therefore, the key to achieving required chemoselectivity is a function of reaction conditions, which includes the nature and ratio of the starting reagents. A consequence of this therefore, is that linear and macrocyclic Schiff bases may be obtained [15]. The introduction of template agents often serves as a reliable method to prevent oligocondensation and switch the reaction process toward forming macrocyclic Schiff bases [15] [16] [17]. Additionally, it has also been established that Schiff bases that contain aryl substituents are substantially more stable [15] [18]. The physical and chemical properties of these bases may therefore be tuned by varying their peripheral functionalities and their template agent [16] [19] [20] [21].

Macrocyclic Schiff bases have been previously reported as biomimetic model compounds due to their closeness to natural proteins and enzymes. As such they have been reported to be good enzyme inhibitors; therefore, they have exhibited good antimicrobial activity [19] [20]. Furthermore because of the number of donor atoms, they possess the capability to extract selectively a particular metal ion from a mixture of cations [21] [22]. The increasing prevalence of antibacterial resistant infectious coupled with the emergence of new diseases has created a therapeutic gap that portends on the emergent probable health crisis. Therefore, there is an urgent need for the discovery of new compounds as antimicrobial agents with broad spectrum of activity [23] [24]. Another serious threat to human and aquatic life is the pollution of water bodies caused by trace metal ions. This has necessitated the development of effective and efficient recoveries of some of these trace metals from waste water [25] [26]. The removal of heavy metals from the environment is an urgent concern due to their persistence without degradation. Methods for the removal of these metal ions are varied; however chemical methods are most suitable treatments for toxic inorganic compounds produced from various industries which cannot be removed from 
any biological and physical techniques and this includes chemical precipitation [25]. Most of the heavy metals are well known toxic and carcinogenic agents and represent a serious threat to the human population and the fauna and flora of the receiving water bodies as they are persistent and non-biodegradable [25] [26].

Although condensation products of aromatic dialdehydes and diamines have been reported and these include $[2+2]$ macrocycle obtained by the condensation reaction of isoterephthalaldehyde and ethane-1,2-diamine [27]. However, to the best of our knowledge $[2+2]$ and $[1+2]$ condensation product of benzene-1,4-dicarboxaldehyde with propane-1,2-diamine have not been reported. For this reason, we decided to investigate the syntheses of these macrocyclic and linear ligands and study their application as antimicrobial and complexing agents. Teraazamacrocyclic and linear ligands were synthesized because of the much stronger association of nitrogen atoms in relation to oxygen with transition-metal ions [16] [22]. In view of the above, in the present paper, we report the syntheses and characterization of macrocyclic Ligands 1 and 2 via the reaction of $[2+2]$ condensation reaction of benzene-1,4-dicarboxaldehyde and two diamines; ethane-1,2-diamine and propane-1,2-diamine (Figure 1). They were characterized, by ${ }^{1} \mathrm{H}$ NMR, UV-Vis and infra-red spectroscopy and mass spectrometry. Coordination compounds of each ligand were further synthesized using $\mathrm{Ni}(\mathrm{II})$ and $\mathrm{Cu}(\mathrm{II})$ ions. These were characterized using Uv-vis, infrared spectroscopy, magnetic susceptibility and energy dispersion X-ray spectroscopy EDX. Additionally, $[1+2]$ condensation products of benzene-1,4-dicarboxaldehyde and two diamines; ethane-1,2-diamine and propane-1,2-diamine were obtained via template syntheses, these were demetellated to afford linear Schiff bases: Ligands 3 and 4. Both were characterized using ${ }^{1} \mathrm{H}$ and ${ }^{13} \mathrm{C}$ NMR, UV-Vis and infra-red spectroscopy and mass spectrometry. Coordination compounds of Ligands 3 and 4 with $\mathrm{Ni}(\mathrm{II})$ and $\mathrm{Cu}(\mathrm{II})$ were also obtained. They were characterized Uv-vis, infrared spectroscopy, mass spectrometry, magnetic susceptibility and EDX. The ligands and their coordination compounds were analyzed for their antimicrobial activity.<smiles>O=Cc1ccc(C=O)cc1</smiles>

a<smiles>NCCN</smiles>

b<smiles>CC(N)CN</smiles>

C

Figure 1. $\mathrm{a}=$ benzene-1,4-dicarboxaldehyde; $\mathrm{b}=$ ethane-1,2-diamine; $c$ = propane-1,2-diamine. 


\section{Material and Method}

All starting materials and solvents used were purchased from Aldrich and Fluka and were used without further purification. The melting points were determined on a Gallenhamp melting point apparatus and are uncorrected. The infrared spectra were recorded in the region $4000-400 \mathrm{~cm}^{-1}$ on a Nicolet 410 impact Fourier-Transform infrared spectrophotometer. Electronic transitions were measured on a Varian Cary $50 \mathrm{UV}$-visible spectrophotometer; measurements were made from 200 to $800 \mathrm{~nm}$. Magnetic susceptibility measurements were carried out at room temperature using a Sherwood scientific balance with $\left[\mathrm{HgCo}(\mathrm{SCN})_{4}\right]$ as standard. EDX analyses were obtained using Shimadzu Ray ny EDX 720. The mass spectrum was obtained on a BrukerSer\# 10390 micrOTOF-Q II mass spectrometer, using atmospheric pressure and chemical ionization APCI. NMR spectra were recorded on a Bruker spectrophotometer topspin2.1PL6 model ultra-shield plus at $600 \mathrm{MHz}$ for ${ }^{1} \mathrm{H}$ NMR spectrum and 150 $\mathrm{MHz}$ for ${ }^{13} \mathrm{C}$ spectrum in DMSO- $\mathrm{d}_{6}$ with TMS as internal standard. Screening of the compounds for antimicrobial activity was carried out using disc diffusion method. The mole fraction of the ligands to the metal ions was determined using Job's method of continuous variation. The ability of the ligands to extract trace metal ions was studied using liquid-liquid extraction.

The compounds were synthesized using an adaptation of previous reports [27]. Generally, the complexes were synthesized in situ using appropriate metal ions in the corresponding ratio with the desired product. Schiff base complexes were obtained in excellent yield.

\subsection{Syntheses of [2+2] Condensation Tetraazamacrocyclic Ligands and Complexes}

1) Ligand 1: Ligand 1 was synthesized using an adaptation of the previously reported method by Gupta, 1997. Ethane-1,2-diamine (0.72 g, $0.01 \mathrm{M}$ ) was dissolved in $250 \mathrm{~mL}$ of acetonitrile, under magnetic stirring, to this benzene-1,4-dicarboxaldehyde $(1.36 \mathrm{~g}, 0.01 \mathrm{M})$ in $60 \mathrm{~mL}$ acetonitrile was added drop-wise for about $30 \mathrm{~min}$ at room temperature. The reaction mixture was refluxed for $5 \mathrm{~h}$. The yellow precipitate obtained was cooled to room temperature, filtered and washed thoroughly with cold water and then ethanol/water mixture (30:70). The product obtained was recrystallized using chloroform/ethanol mixture (30:70) to yield a pale white precipitate. This was filtrated and dried in a vacuum oven at $60^{\circ} \mathrm{C}$ to afford Ligand 1, which was soluble in chloroform, ethanol and methanol.

Yield: 1.85 g, $58.65 \%$; m.pt/d.t: $112^{\circ} \mathrm{C}-114^{\circ} \mathrm{C}$; IR $\left(\mathrm{cm}^{-1}\right): 1638 v(\mathrm{C}=\mathrm{N}), 1531$ $\mathrm{C}-\mathrm{N})+\mathrm{v}(\mathrm{C}=\mathrm{C}), 1368 \delta(\mathrm{C}-\mathrm{H})+\mathrm{v}(\mathrm{C}=\mathrm{N}) . \mathrm{UV}-\mathrm{Vis}(\mathrm{nm}): 198,243$ and $340 ;{ }^{1} \mathrm{H}$ NMR (600 MHz): DMSO-d $62.49(\mathrm{~s}, 4 \mathrm{H}), 2.87(\mathrm{~s}, 4 \mathrm{H}), 5.42(\mathrm{~s}, 2 \mathrm{H}), 7.19-8.44$ (m, 12H).

2) Ligand 2: An ethanolic solution of propane-1,2-diamine (1.50 g, $0.02 \mathrm{M})$ was added to a solution of benzene-1,4-dicarboxaldehyde (2.67 g, $0.02 \mathrm{M})$ in 250 
$\mathrm{mL}$ of absolute ethanol containing three drops of glacial acetic acid. The reaction mixture was then refluxed for $4 \mathrm{~h}$. The mixture was cooled to room temperature and the solvent removed under reduced pressure by rotavapour until a solid product was formed that was washed with cold ethanol. The product obtained was recrystallized with chloroform/ethanol mixture (30/70). A pale yellow precipitate was obtained which was filtered and dried under vacuum at $60^{\circ} \mathrm{C}$ to give Ligand 2. This was soluble in chloroform, ethanol and methanol.

Yield: 2.05 g, 61.26\%; m.pt: $118^{\circ} \mathrm{C}-120^{\circ} \mathrm{C}$; IR $\left(\mathrm{cm}^{-1}\right): 1640 v(\mathrm{C}=\mathrm{N}), 1300$ $\delta(\mathrm{C}-\mathrm{H})+\mathrm{v}(\mathrm{C}=\mathrm{N})$. UV-Vis $(\mathrm{nm}): 201,250$ and 340; ${ }^{1} \mathrm{H}$ NMR (600 MHz): DMSO-d $65.53(\mathrm{~m}, 12 \mathrm{H}), 1.77(\mathrm{t}, 6 \mathrm{H}), 2.49,(\mathrm{q}, 2 \mathrm{H}), 2.73(\mathrm{~d}, 2 \mathrm{H}) ; \mathrm{m} / z .338 .34$.

3) Compound 1a: Nickel(II) chloride (1.78 g, $0.01 \mathrm{M})$ was dissolved in absolute ethanol $(1.40 \mathrm{~g}, 0.01 \mathrm{M})$. This was added to a refluxing solution of benzene-1,4-dicarboxaldehyde (2.67 g, $0.02 \mathrm{M})$ and ethane-1,2-diamine (1.40 g, 0.02 $\mathrm{M})$ in ethanol $(250 \mathrm{~mL})$ with the addition of glacial acetic acid $(2 \mathrm{~mL})$. The reaction mixture was refluxed for $5 \mathrm{~h}$. A pale yellow precipitate was obtained. This was recrystallized using methanol/ethanol mixture $(10 \mathrm{~mL})$.

Yield: 2.67 g, $71.28 \%$; m.pt: $216^{\circ} \mathrm{C}-218^{\circ} \mathrm{C}$; metal composition (\%): calc.11.91; found: 12.76; IR $\left.\left(\mathrm{cm}^{-1}\right): 3661 v(\mathrm{O}-\mathrm{H}), 1638 v(\mathrm{C}=\mathrm{N}), 1589 v \mathrm{C}-\mathrm{N}\right)+\mathrm{v}(\mathrm{C}=\mathrm{C}), 1350$ $\delta(\mathrm{C}-\mathrm{H})+\mathrm{v}(\mathrm{C}=\mathrm{N}), 1482 v\left(\mathrm{C}=\mathrm{N}+\mathrm{CH}_{2}\right), 609 v(\mathrm{M}-\mathrm{O}), 555 v(\mathrm{M}-\mathrm{N}) ; \mathrm{UV}-\mathrm{V}$ is $(\mathrm{nm})$ : 203, 256, 365, 564 and 815; $\mu_{\text {eff: }} .98$ BM; $m / Z$. 470.

A similar procedure was adopted for the syntheses of the following complexes.

4) Compound 1b: Copper(II) chloride (0.71 g, $0.005 \mathrm{M})$, benzene-1,4-dicarboxaldehyde $(1.35 \mathrm{~g}, 0.01 \mathrm{M})$ and ethane-1,2-diamine $(0.70 \mathrm{~g}, 0.01 \mathrm{M})$ in absolute ethanol $(350 \mathrm{~mL})$ with the addition of glacial acetic acid $(2 \mathrm{~mL})$. The reaction mixture was refluxed for $5 \mathrm{~h}$, pale blue.

Yield: 2.14 g, 56.29\%; m.pt: $132^{\circ} \mathrm{C}-134^{\circ} \mathrm{C}$ (d); metal composition (\%): calc.13.05; found: 13.71; IR $\left(\mathrm{cm}^{-1}\right): 3661 v(\mathrm{O}-\mathrm{H}), 1639 v(\mathrm{C}=\mathrm{N}), 1597 v(\mathrm{C}-\mathrm{N})+$ $\mathrm{v}(\mathrm{C}=\mathrm{C}), 1366 \delta(\mathrm{C}-\mathrm{H})+\mathrm{v}(\mathrm{C}=\mathrm{N}), 1484 v\left(\mathrm{C}=\mathrm{N}+\mathrm{CH}_{2}\right), 553 v(\mathrm{M}-\mathrm{N}), 638 v(\mathrm{M}-\mathrm{O})$ $1082 v(\mathrm{C}-\mathrm{OH})$; UV-Vis (nm): 267 and 345, 652, 632; $\mu_{\text {eff: }} 2.01 \mathrm{BM}$.

5) Compound 2a: Nickel(II) chloride (0.91 g, $0.005 \mathrm{M})$. benzene-1,4-dicarboxaldehyde $(1.33 \mathrm{~g}, 0.01 \mathrm{M})$ and propane-1,2-diamine $(0.75 \mathrm{~g}, 0.01 \mathrm{M})$ in absolute ethanol $(350 \mathrm{~mL})$ with the addition of glacial acetic acid $(2 \mathrm{~mL})$ was refluxed. The light green precipitate obtained, was filtered washed with methanol and dried under vacuum at $60^{\circ} \mathrm{C}$.

Yield: 2.06 g, 52.59\%; m.pt/d.t: $180^{\circ} \mathrm{C}-181^{\circ} \mathrm{C}$; metal composition (\%): calc.13.63; found: 12.48; IR: $3638 v(\mathrm{O}-\mathrm{H}), 1643 v(\mathrm{C}=\mathrm{N}), 1597 v \mathrm{C}-\mathrm{N})+\mathrm{v}(\mathrm{C}=\mathrm{C})$, $563 v(\mathrm{M}-\mathrm{N})$; UV-Vis (nm): 202, 254 and 376, 545, 689; $\mu_{\mathrm{eff}}: 0.45 \mathrm{BM}, \mathrm{m} / z=$ 411.39 .

6) Compound 2b: A mixture of copper(II) chloride $(0.74 \mathrm{~g}, 0.005 \mathrm{M})$, benzene-1,4-dicarboxaldehyde $(1.34 \mathrm{~g}, 0.01 \mathrm{M})$ and propane-1,2-diamine $(0.75 \mathrm{~g}$, $0.01 \mathrm{M})$ in absolute ethanol $(400 \mathrm{~mL})$ with the addition of glacial acetic acid (2 $\mathrm{mL}$ ) was refluxed. A pale green precipitate was obtained which was filtered, washed with methanol and dried under vacuum $60^{\circ} \mathrm{C}$. 
Yield: $2.38 \mathrm{~g}, 59.83 \%$; m.pt/d.t: $213^{\circ} \mathrm{C}-214^{\circ} \mathrm{C}$; metal composition (\%): calc.16.33; found: 17.12; $\left.\operatorname{IR}\left(\mathrm{cm}^{-1}\right): 1540 \downarrow \mathrm{C}-\mathrm{N}\right)+\mathrm{v}(\mathrm{C}=\mathrm{C}), 538 v(\mathrm{M}-\mathrm{N}), 609$; UV-Vis (nm): 205 and 275, 525, 750; $\mu_{\text {eff: }} 1.87 \mathrm{BM} ; \mathrm{m} / \mathrm{z} .398$.

\subsection{Syntheses of $[1+2]$ Condensation Products and Ligands}

1) Compound 3a: Nickel(II) chloride $(0.89 \mathrm{~g}, 0.005 \mathrm{M})$ was dissolved in absolute ethanol. This was added to a refluxing solution of benzene-1,4-dicarboxaldehyde $(0.69 \mathrm{~g}, 0.005 \mathrm{M})$ and 1,2-diaminoethane $(0.70 \mathrm{~g}, 0.01 \mathrm{M})$ in absolute ethanol (250 $\mathrm{mL})$ with the addition of glacial acetic acid $(2 \mathrm{~mL})$ was added. The reaction mixture was refluxed for $5 \mathrm{~h}$. A pale yellow precipitate was obtained. This was recrystallized using methanol/ethanol mixture $(10 \mathrm{~mL})$.

Yield: 1.69 g, $61.26 \%$; m.pt/d.t: $115^{\circ} \mathrm{C}-117^{\circ} \mathrm{C}$ (d); metal composition (\%): calc.14.62; found: 15.64; IR $\left(\mathrm{cm}^{-1}\right): 3406 v(\mathrm{O}-\mathrm{H}), 3201 v(\mathrm{~N}-\mathrm{H}), 1654 v(\mathrm{C}=\mathrm{N})$, $1538 v(\mathrm{C}-\mathrm{N})+\mathrm{v}(\mathrm{C}=\mathrm{C}), 1376 \delta(\mathrm{C}-\mathrm{H})+\mathrm{v}(\mathrm{C}=\mathrm{N}), 1454\left(\mathrm{C}=\mathrm{N}+\mathrm{CH}_{2}\right), 548$ $v(\mathrm{M}-\mathrm{N}), 645 v(\mathrm{M}-\mathrm{O})$; UV-Vis $(\mathrm{nm}): 244$ and 342, 560, 815; $\mu_{\text {eff: }} .37$; $[\mathrm{M}+1]$ $m / z 384$.

2) Compound 3b: Copper(II) chloride (0.74 g, $0.005 \mathrm{M})$, benzene-1,4-dicarboxaldehyde $(0.71 \mathrm{~g}, 0.005 \mathrm{M})$ and 1,2-diaminoethane $(0.70 \mathrm{~g}, 0.01 \mathrm{M})$ in absolute ethanol $(300 \mathrm{~mL})$ with the addition of glacial acetic acid $(2 \mathrm{~mL})$. The reaction mixture was refluxed for $5 \mathrm{~h}$.

Yield: 1.16 g, $52.58 \%$; m.pt: $214^{\circ} \mathrm{C}-215^{\circ} \mathrm{C}$; metal composition (\%): calc.23.05; found: 22.43; IR $\left(\mathrm{cm}^{-1}\right): 3150 v(\mathrm{~N}-\mathrm{H}), 1638 v(\mathrm{C}=\mathrm{N}), 1538 v(\mathrm{C}-\mathrm{N})+\mathrm{v}(\mathrm{C}=\mathrm{C})$, $1346 \delta(\mathrm{C}-\mathrm{H})+\mathrm{v}(\mathrm{C}=\mathrm{N}), 539 v(\mathrm{M}-\mathrm{N}) ; \mathrm{UV}-\mathrm{Vis}(\mathrm{nm}): 232,280,634,740 ; \mu_{\text {eff: }} .47$; $\mathrm{m} /$ z. 282.27 .

3) Compound 3c: Sodium chloride solution (0.32 g, $0.005 \mathrm{M})$, benzene-1,4-dicarboxaldehyde $(0.68 \mathrm{~g}, 0.005 \mathrm{M})$ and 1,2-diaminoethane $(0.72 \mathrm{~g}$, $0.01 \mathrm{M})$ in absolute ethanol $(300 \mathrm{~mL})$ with the addition of glacial acetic acid (2 $\mathrm{mL}$ ). The reaction mixture was refluxed for $5 \mathrm{~h}$.

Yield: 1.23 g, $51.26 \%$; m.pt: $128^{\circ} \mathrm{C}-130^{\circ} \mathrm{C}$; IR $\left(\mathrm{cm}^{-1}\right): 3352 v(\mathrm{~N}-\mathrm{H}), 1623$ $v(\mathrm{C}=\mathrm{N}), 1342 \delta(\mathrm{C}-\mathrm{H})+\mathrm{v}(\mathrm{C}=\mathrm{N})$; UV-Vis $(\mathrm{nm}): 214,721$.

4) Compound 4a: Nickel(II) chloride (0.93 g, $0.005 \mathrm{M})$ was dissolved in ethanol. benzene-1,4-dicarboxaldehyde $(0.71 \mathrm{~g}, 0.005 \mathrm{M})$ and propane-1,2-diamine $(0.75 \mathrm{~g}, 0.01 \mathrm{M})$ in absolute ethanol $(350 \mathrm{~mL})$ with the addition of glacial acetic acid $(2 \mathrm{~mL})$ was added was refluxed. An olive green precipitate was obtained, which was filtered washed with methanol and dried, olive green.

Yield: 2.00 g, $65.83 \%$; m.pt: $210^{\circ} \mathrm{C}-212^{\circ} \mathrm{C}$ (d); metal composition (\%): calc.17.55; found: 19.01; IR $\left(\mathrm{cm}^{-1}\right)$ : $2348(\mathrm{C}-\mathrm{OH}), 1634 \mathrm{v}(\mathrm{C}=\mathrm{N}), 1532 v(\mathrm{C}-\mathrm{N})+$ $\mathrm{v}(\mathrm{C}=\mathrm{C}), 1439 v\left(\mathrm{C}=\mathrm{N}+\mathrm{CH}_{2}\right) 1358 \delta(\mathrm{C}-\mathrm{H})+\mathrm{v}(\mathrm{C}=\mathrm{N}), 579 v(\mathrm{M}-\mathrm{N})$; UV-Vis (nm): 234, 334, 540, 670; $\mu_{\text {eff: }} 0.83$.

5) Compound 4b: A mixture of copper(II) chloride $(0.72 \mathrm{~g}, 0.005 \mathrm{M})$. benzene-1,4-dicarboxaldehyde $(0.70 \mathrm{~g}, 0.005 \mathrm{M})$ and propane-1,2-diamine (0.75 g, $0.01 \mathrm{M})$ in absolute ethanol $(250 \mathrm{~mL})$ with the addition of glacial acetic acid (2 $\mathrm{mL}$ ) was added was refluxed. 
Yield: $1.88 \mathrm{~g}, 60.72 \%$; m.pt: $108^{\circ} \mathrm{C}-111^{\circ} \mathrm{C}$; metal composition (\%): calc.18.73; found: 18.35; IR $\left(\mathrm{cm}^{-1}\right): 3267 v(\mathrm{~N}-\mathrm{H}), 1527 v(\mathrm{C}-\mathrm{N})+\mathrm{v}(\mathrm{C}=\mathrm{C}), 1446 v(\mathrm{C}=\mathrm{N}+$ $\left.\mathrm{CH}_{2}\right) 1356 \delta(\mathrm{C}-\mathrm{H})+\mathrm{v}(\mathrm{C}=\mathrm{N}), 552 \gamma(\mathrm{M}-\mathrm{N})$; UV-Vis $(\mathrm{nm}): 275,346,568,780$; $\mu_{\text {eff: }}$ $2.43 ; \mathrm{m} / \mathrm{z} 310$.

6) Compound 4c: A mixture of sodium chloride solution ( $0.31 \mathrm{~g}, 0.005 \mathrm{M})$. benzene-1,4-dicarboxaldehyde $(0.70 \mathrm{~g}, 0.005 \mathrm{M})$ and propane-1,2-diamine $(0.72$ g, $0.01 \mathrm{M})$ in absolute ethanol $(250 \mathrm{~mL})$ with the addition of glacial acetic acid (2 $\mathrm{mL}$ ) was added was refluxed.

Yield: 1.47 g, 54.84\%; m.pt: $144^{\circ} \mathrm{C}-146^{\circ} \mathrm{C}$; IR $\left(\mathrm{cm}^{-1}\right): 3348 v(\mathrm{~N}-\mathrm{H}), 1631$ $v(\mathrm{C}=\mathrm{N}), 1454 v\left(\mathrm{C}=\mathrm{N}+\mathrm{CH}_{2}\right) 1343 \delta(\mathrm{C}-\mathrm{H})+\mathrm{v}(\mathrm{C}=\mathrm{N}) ; \mathrm{UV}-\mathrm{Vis}(\mathrm{nm}): 206,246$, 395.

7) Ligand 3: Ligand 3 was obtained via template synthesis to obtain compound $3 \mathrm{c}$. The sodium ion was removed from compound $3 \mathrm{c}$ by heating compound $3 \mathrm{c}(1.12 \mathrm{~g}, 0.005 \mathrm{M})$ under reflux $\mathrm{CHCl}_{3} /$ perchloric acid (20:5) solution mixture $(250 \mathrm{~mL})$, and cooled. This was made basic by the use of $\mathrm{NaOH}$. The organic layer was separated, washed once with $10 \%$ aqueous $\mathrm{NaOH}(50 \mathrm{~mL})$, and dried over anhydrous $\mathrm{Na}_{2} \mathrm{SO}_{4}$ and filtered. The resultant filtrate was absorbed into a silica gel, column chromatographed and eluted with $\mathrm{CHCl}_{3} / \mathrm{n}$-hexane $(5: 1)$. Slow evaporation of the eluate and filtration gave a yellow solid, which was recrystallized by slow diffusion of $\mathrm{CHCl}_{3}$ /ethanol mixture.

Yield: 1.20 g. $55.26 \%$; m.pt: $110^{\circ} \mathrm{C}-112^{\circ} \mathrm{C}$; IR $\left(\mathrm{cm}^{-1}\right): 3345 v(\mathrm{~N}-\mathrm{H}), 1623$ $\mathrm{v}(\mathrm{C}=\mathrm{N}) .1525 v(\mathrm{C}-\mathrm{N})+\mathrm{v}(\mathrm{C}=\mathrm{C})$ and $1340 \mathrm{~cm}^{-1} \delta(\mathrm{C}-\mathrm{H})+\mathrm{v}(\mathrm{C}=\mathrm{N}) . \mathrm{UV}-\mathrm{V}$ is $(\mathrm{nm})$ : 232 and 324; ${ }^{1} \mathrm{H}$ NMR (600 MHz): $\mathrm{CHCl}_{3}-\mathrm{d}_{6} \delta 0.03(\mathrm{~s}, 2 \mathrm{H}), 1.21(\mathrm{~s}, 2 \mathrm{H}), 5.26(\mathrm{q}$, $2 \mathrm{H}$ ), $7.24(\mathrm{~s}, 2 \mathrm{H}), 7.87-8.22(\mathrm{~m}, 4 \mathrm{H}) \cdot 10.24-9.95(\mathrm{~m}, 2 \mathrm{H}) ;{ }^{13} \mathrm{C}$ NMR (150 $\mathrm{MHz}): \mathrm{CHCl}_{3}-\mathrm{d}_{6} \delta 77.01,77.23,77.44,140.21,140.00,129.74$ - 130.8, 181.77, 191.67; $[\mathrm{M}+1] \mathrm{m} / \mathrm{z} 236$.

8) Ligand 4: A similar method as described in section 2.2.5 was used to demetallate compound $4 \mathrm{c}(2.01 \mathrm{~g}, 0.005 \mathrm{M})$ afforded a pale yellow precipitate.

Yield: 1.26 g, 53.45\%; m.pt: $118^{\circ} \mathrm{C}-120^{\circ} \mathrm{C}$; IR $\left(\mathrm{cm}^{-1}\right): 3345 v(\mathrm{~N}-\mathrm{H}), 1618$ $\mathrm{v}(\mathrm{C}=\mathrm{N}), 1516 v(\mathrm{C}-\mathrm{N})+\mathrm{v}(\mathrm{C}=\mathrm{C}), 1326 \delta(\mathrm{C}-\mathrm{H})+\mathrm{v}(\mathrm{C}=\mathrm{N}) . \mathrm{UV}-\mathrm{Vis}(\mathrm{nm}): 260$ and 324. ${ }^{1} \mathrm{H}$ NMR (600 MHz): $\mathrm{CHCl}_{3}-\mathrm{d}_{6} \delta 0.03$ (s, 2H), 0.83 (s, 2H), 1.24 and 1.21 (d, $3 \mathrm{H}), 1.944(\mathrm{~s}, 2 \mathrm{H}), 3.45(\mathrm{~s}, 2 \mathrm{H}), 7.24(\mathrm{~s}, 2 \mathrm{H}), 8.22(\mathrm{~m}, 4 \mathrm{H}), 10.10(\mathrm{~m}, 2 \mathrm{H}) ;{ }^{13} \mathrm{C}$ NMR (150 MHz): $\mathrm{CHCl}_{3}-\mathrm{d}_{6} \delta 77.01,77.23,77.44,130.48,140.21,191.66$.

\subsection{Antimicrobial Activity}

The organisms used were five Gram-positive and three Gram-negative bacteria and two fungi. These were Staphylococcus aureus (ATCC 29213), Staphylococcus epidermidis (clinical strain), Bacillus subtilis 12 (NCIB 3610), Bacillus subtilis 82 (NCIB 6349), Clostridium sp. (NCIB 532), Klebsiella pneumonia (clinical strain), Pseudomonas aeruginosa (ATCC 27853), Escherichia coli (ATCC 25922), Candida albicans (ATCC 24433) and Candida pseudotropicalis (NCYC $6)$, respectively. The resulting solutions were used to soak sterile Whatman No 2 discs (diameter of $6 \mathrm{~mm}$ ) and allowed to dry in an oven at $50^{\circ} \mathrm{C}$ ). The discs were then utilized to determine antibacterial and antifungal activities as previously 
described by Aiyelabola et al. [28]. Discs that were impregnated with imipenem and chlorhexidine were used as positive controls for bacteria and fungi, respectively. Zones of inhibition were used as indices of antimicrobial actions.

\subsection{Determination of the Mole Ratio of the Ligands to the Metal Ions in the Formation of the Complexes}

The mole ratio of the ligands to the metal ions and as such the probable formulae of the complexes with respect to the metal ions and the ligand was determined spectrophotometrically using Job's method of continuous variation, The procedure used was an adaptation of previously described method [29].

1) Compound 1a: A $1 \mathrm{ml}$ solution of nickel(II) chloride hexahydrate $(1.19 \mathrm{~g}$, $0.005 \mathrm{M})$, was added into a beaker, a solution of Ligand $1(9 \mathrm{ml}, 1.17 \mathrm{~g}, 0.005 \mathrm{M})$ was added with stirring. The solution obtained was poured into a cuvette and absorbance was measured using water as reference. Absorbance for nine different concentration ratios varying from 1:9 to 9:1 with respect to nickel(II) chloride: Ligand 1 was obtained.

Similar method was used as well for nickel(II) chloride hexahydrate (1.18 g, $0.005 \mathrm{M}$ ) and Ligands 2, 3 and 4 using $0.005 \mathrm{M}$ concentration in all cases.

2) Compound 1b: Similar method as described in section 2.4.1 was used for copper(II) chloride hexahydrate $(1.21 \mathrm{~g}, 0.005 \mathrm{M})$ and Ligand $1(1.55 \mathrm{~g}, 0.005 \mathrm{M})$.

Additionally, similar method was further used for copper(II) chloride hexahydrate $(1.24 \mathrm{~g}, 0.005 \mathrm{M})$ and Ligands 2, 3 and 4 using $0.005 \mathrm{M}$ concentration in all cases.

\subsection{Extraction Procedure}

1) Extraction at $\mathrm{pH}$ 4.5: Aqueous solutions of the metal salt of. cadmium chloride $\left(0.028 \mathrm{~g}, 1.5 \times 10^{-4} \mathrm{M}\right)$, zinc chloride $\left(0.021 \mathrm{~g}, 1.5 \times 10^{-4} \mathrm{M}\right)$ and lead chloride $\left(0.042 \mathrm{~g}, 1.5 \times 10^{-4} \mathrm{M}\right)$ in buffer solution of $\mathrm{pH} 4.5$ were equilibrated with equal volume of the chloroform solution of the Ligands $1,2,3$ and $4\left(5 \times 10^{-4}\right.$ $\mathrm{M})$ in separate conical flasks. The mixture was shaken using a mechanical shaker at $25^{\circ} \mathrm{C}$. The aqueous and organic layers were well agitated to enhance the homogeninuty of the mixture. After agitation, the solutions were allowed to stand for $15 \mathrm{~min}$. The solutions were transferred to a separating funnel where the aqueous layer was allowed to separate from the organic layer and transferred to a separating funnel where the aqueous layer was allowed to separate from the organic layer and transferred into a volumetric flask. The extraction was repeated with chloroform $(5 \mathrm{~mL})$. The concentration of the metal ions in the aqueous and organic phase was determined using XRF/AAS.

2) Extraction at $\mathrm{pH}$ 10: Similar method as described in Section 2.5.1 was carried out, however a buffer solution of $\mathrm{pH} 10$ was used in this instance.

The obtained results are expressed in terms of the extraction ratio $R(\%)$ :

$$
R \%=\frac{\left[M_{i}\right]-\left[M_{f}\right] \times 100}{\left[M_{i}\right]}
$$




$$
D=\frac{\left[M_{i}\right]-\left[M_{f}\right]}{\left[M_{i}\right]}
$$

where $\left[M_{i}\right]$ and $\left[M_{f}\right]$ are the initial and final concentrations in the aqueous phase.

The extraction efficiency E\% may be expressed as Equation (3) [30]

$$
E \%=\frac{D}{D+A / O} \times 100
$$

where $D$ is the distribution ratio;

$A=$ concentration of the metal ion in aqueous phase;

$O=$ concentration of the metal ion in organic phase.

\section{Results and Discussion}

\section{1. [2 + 2] Macrocyclic Ligand and Complexes}

\subsubsection{Ligand 1}

The infrared spectrum of Ligand 1 provided evidence suggesting that cyclization occurred by the appearance of a band at $1638 \mathrm{~cm}^{-1}$ associated with the imine stretching frequency [31] [32] [33]. This was supported by the disappearance of bands associated with carbonyl and amine groups, which were present in the starting material. Additional bands observed in this spectrum include stretching frequencies at $1531,1368 \mathrm{~cm}^{-1}$ ascribed to the $v(\mathrm{C}-\mathrm{N})+\mathrm{v}(\mathrm{C}=\mathrm{C})$ and $\delta(\mathrm{C}-\mathrm{H})+$ $\mathrm{v}(\mathrm{C}=\mathrm{N})$ frequencies respectively, this thus further served as an indication that macrocyclization had occurred [15] [31] [32].

The UV-Vis spectrum of this Ligand exhibited three absorption peaks at 198, 243 and $340 \mathrm{~nm}$, which were assigned to $\mathrm{n} \rightarrow \sigma^{*}, \mathrm{n} \rightarrow \pi^{*}$ and $\pi \rightarrow \pi^{*}$ transitions respectively of the major chromophores of the ligand [32] [33].

The proton NMR in $\mathrm{CDCl}_{3}$ exhibited signals at $\delta 2.49(\mathrm{~s}, 4 \mathrm{H})$ and $2.87(\mathrm{~s}, 4 \mathrm{H})$. These observed two singlets were assigned to the methylene protons of the ring, and they have been reported to be due to inherent ring strain present in the macrocycle, which renders it a non-planar structure [27] [32] [33]. Additional signals observed in this spectrum include a multiplet at $7.19-8.44(\mathrm{~m}, 12 \mathrm{H})$. This is in good agreement with that observed by previous researchers [32] [33] [34]. The absence of the aldehydic protons, which existed in benzene-1,4-dicarboxaldehyde, in this spectrum also suggests the formation of the imine. Corroborating this was the signal observed at $5.42 \mathrm{ppm}$, consistent with a methine proton [34] [35]. This therefore serves as evidence that a Schiff base was obtained.

\subsubsection{Ligand 2}

Similar to that of Ligand 1 the infrared spectrum of Ligand 2 exhibited the imine stretching frequency at $1640 \mathrm{~cm}^{-1}$ suggestive that of the formation of a Schiff base [31] [32] [33]. The disappearance of bands associated with carbonyl and amine groups also confirmed this. Probable macrocyclization is however suggested by this. 
The UV-Vis spectrum of the ligand exhibited three absorption peaks at 201, 250 and $340 \mathrm{~nm}$ which were assigned to $\mathrm{n} \rightarrow \sigma^{\star}, \mathrm{n} \rightarrow \pi^{*}$ and $\pi \rightarrow \pi^{\star}$ transitions respectively [32] [33].

The ${ }^{1} \mathrm{H}$ NMR spectrum exhibited a signal observed at $\delta 5.53 \mathrm{ppm}(\mathrm{m}, 12 \mathrm{H})$ and was assigned to the azomethine proton in conjugation with aromatic protons $(\mathrm{Ar}-\mathrm{HC}=\mathrm{N})$ [32] [33]. This was suggested by the broadness of the signal. The spectrum also revealed a signal at $\delta 1.77 \mathrm{ppm}(\mathrm{t}, 6 \mathrm{H})$ characteristic of the methyl proton $\left(=\mathrm{N}-\mathrm{CH}-\mathrm{CH}_{3}\right)$, it was therefore assigned to the methyl substituent of the side chain [32] [33]. The signals observed at $\delta 2.49 \mathrm{ppm}(\mathrm{q}, 2 \mathrm{H})$ and $\delta=$ $2.73 \mathrm{ppm}(\mathrm{d}, 2 \mathrm{H})$ were ascribed to the methylene proton of the carbon atom coupled to the azomethine nitrogen atom and the methine proton of the carbon atom attached to the methyl substituent respectively, $\left(=\mathrm{N}-\mathrm{CH}_{2}-\mathrm{CH}\right)$ and $\left(=\mathrm{N}-\mathrm{CH}-\mathrm{CH}_{3}\right)$ [32] [33] [34] [35]. Further lending corroboration to macrocyclization was the absence of the aldehyde proton of the starting material.

\subsection{Complexes of Ligands 1 and 2}

\subsubsection{Infrared}

The infrared spectra of all the complexes suggested the presence of imine bonds in the complexes with each complex exhibiting the $\mathrm{v}(\mathrm{C}=\mathrm{N})$ at $\sim 1637 \mathrm{~cm}^{-1}$ [31] [32] [33]. The absence of bands at $1750 \mathrm{~cm}^{-1}$ present in the starting material attributable to the $\mathrm{C}=\mathrm{O}$ stretching of an aldehyde, indicated that condensation and cyclization occurred. This was further confirmed by the absence of the $\mathrm{v}(\mathrm{N}-\mathrm{H})$ in the spectrum of the complexes [31] [32] [33]. A comparison of the infrared spectra of the complexes with those of the Ligands, 1 and 2, indicated that there was no significant shift in the $v(\mathrm{C}=\mathrm{N})$ for the complexes as compared to those of the ligands. On the other hand significant shifts were observed for $v(\mathrm{C}-\mathrm{N})+$ $\mathrm{v}(\mathrm{C}=\mathrm{C})$ for all the complexes. For Ligand 1 the observed $\delta(\mathrm{C}-\mathrm{H})+\mathrm{v}(\mathrm{C}=\mathrm{N})$ at $1368 \mathrm{~cm}^{-1}$ shifted to lower frequencies for complexes $1 \mathrm{a}$ and $1 \mathrm{~b}$. Conversely the $v\left(\mathrm{C}=\mathrm{N}+\mathrm{CH}_{2}\right)$ observed at $1482 \mathrm{~cm}^{-1}$ in Ligand 1 , shifted to higher frequencies in the spectra of complexes $1 \mathbf{a}$ and $\mathbf{1 b}$ [30] [31] [32]. The spectra of complexes $1 \mathrm{a}$ and $\mathrm{1b}$ exhibited bands at about $3638 \mathrm{~cm}^{-1}$, this suggests the complexation of a hydroxyl substituent and is suggestive of coordination of ethanol, the solvent, to the metal ion [31] [32] [33]. This was supported by the $v(\mathrm{M}-\mathrm{O})$ stretching frequency observed at about $\sim 609 \mathrm{~cm}^{-1}$ for the complexes and the $v(\mathrm{C}-\mathrm{OH})$ at $1082 \mathrm{~cm}^{-1}$ in the case of $1 \mathrm{~b}$ [31]. Compound 2a also exhibited a signal at 3638 which was ascribed to $v(\mathrm{O}-\mathrm{H})$, however we suggest it may be due to water of crystallization. This is based on the result obtained from the metal analysis and mass spectrum of 2a. Additionally this is also because there was no corroborative evidence in the infrared spectrum to indicate coordination of an oxygen atom with the metal ion. Furthermore the presence of the $v\left(\mathrm{C}=\mathrm{N}+\mathrm{CH}_{2}\right)$ and $\delta(\mathrm{C}-\mathrm{H})+\mathrm{v}(\mathrm{C}=\mathrm{N})$ in complexes $1 \mathrm{a}$ and $\mathbf{1 b}$ and its absence in compounds $2 \mathrm{a}$ and $2 \mathrm{~b}$ was suggestive of the fact that both $\mathrm{C}=\mathrm{NCH}_{2}$ are trans to each other in the complexes [31] [32] [33]. As a consequence, this suggests therefore that in the case of complexes $\mathbf{2 a}$ and $\mathbf{2 b}$ the trans structural orientation is preferential as a 
result of its stability [31] [32] [33].

\subsubsection{Electronic Spectra and Magnetic Moment}

1) Compound 1a: The spectrum for the Ni(II) complex exhibited two intense bands at 203 and $365 \mathrm{~nm}$, it also showed a medium band at $256 \mathrm{~nm}$. These were assigned to intraligand transitions $\sigma \rightarrow \pi^{*}, \mathrm{n} \rightarrow \pi^{*}$ and $\pi \rightarrow \pi^{*}$ respectively [32] [33]. The $d-d$ transition bands at 564 and $815 \mathrm{~nm}$ which were assigned to spin allowed transitions of ${ }^{3} \mathrm{~A}_{2 g}(\mathrm{~F}) \rightarrow{ }^{3} \mathrm{~T}_{1 \mathrm{~g}}(\mathrm{~F})$ and ${ }^{3} \mathrm{~A}_{2 \mathrm{~g}}(\mathrm{~F}) \rightarrow{ }^{3} \mathrm{~T}_{1 \mathrm{~g}}(\mathrm{P})$ suggestive of an octahedral geometry [36] [37] [38]. The magnetic moment of 2.98 BM indicated two unpaired electrons per nickel ion, further validates an octahedral geometry for the complex [37] [38].

2) Compound $1 \mathrm{~b}$ : The electronic spectrum of $1 \mathrm{~b}$ exhibited a well-resolved band at $652 \mathrm{~nm}$ and a weak band at $632 \mathrm{~nm}$ assignable to ${ }^{2} \mathrm{~B}_{1 \mathrm{~g}} \rightarrow{ }^{2} \mathrm{~A}_{1 \mathrm{~g}}$ and ${ }^{2} \mathrm{~B}_{1 \mathrm{~g}} \rightarrow$ ${ }^{2} E_{g}$ transitions, which suggested an octahedral geometry [31] [32]. Intraligand transitions were observed at 215, 281 and $392 \mathrm{~nm}$ [36] [37] [38]. This proposed geometry was corroborated by its magnetic moment of $2.01 \mathrm{BM}$, indicative of a tetragonally distorted octahedral geometry [37] [39]. This is in agreement with that proposed by previous workers for similar compounds [38] [39].

3) Compound 2a: The spectrum for this complex elicited intraligand transition bands at 202, 254 and $376 \mathrm{~nm}$, attributable to $\sigma \rightarrow \pi^{\star}, \mathrm{n} \rightarrow \pi^{\star}$ and $\pi \rightarrow \pi^{\star}$ [31] [32]. It also showed $d-d$ bands at $545,689 \mathrm{~nm}$ which were assigned to spin allowed transitions of ${ }^{3} \mathrm{~T}_{1}(\mathrm{~F}) \rightarrow{ }^{3} \mathrm{~T}_{2}(\mathrm{~F})$ and ${ }^{3} \mathrm{~T}_{1}(\mathrm{~F}) \rightarrow{ }^{3} \mathrm{~A}_{2}(\mathrm{~F})$ suggestive of a square geometry [36] [37] [38]. The magnetic moment of $0.45 \mathrm{BM}$ indicated two unpaired electrons per nickel ion, further validates a square planar geometry for the complex [40].

4) Compound $2 \mathrm{~b}$ : The ultraviolet region of the spectrum displayed two intense bands at 205 and $275 \mathrm{~nm}, \mathrm{n} \rightarrow \sigma^{*}$ and $\mathrm{n} \rightarrow \pi^{*}$ intraligand transitions [32]. The visible region of the spectrum of compound $2 \mathrm{~b}$ displayed a broad band at 676 and a shoulder at $720 \mathrm{~nm}$ assigned to ${ }^{2} \mathrm{~B}_{1} \rightarrow{ }^{2} \mathrm{~A}_{1}$ and ${ }^{2} \mathrm{~B}_{1} \rightarrow{ }^{2} \mathrm{E}_{1}$ transitions. Its magnetic moment of $1.87 \mathrm{BM}$ is indicative of an antiferromagnetic suggests square planar geometry [41]. This proposed geometry was further validated by the molecular ion obtained from its mass spectrum. Similar results have been published for coordination compounds [41].

\subsubsection{Ligand 3}

The infrared spectrum of Ligand 3 exhibited a broad band at $3345 \mathrm{~cm}^{-1}$ assignable to $\mathrm{v}(\mathrm{N}-\mathrm{H})$ of $\mathrm{NH}_{2}$ stretching frequency [31] [32] [33]. This thus suggests that the $[1+2]$ condensation product is not a closed marocycle. This result, however, alludes to its probable open-end nature. This was further corroborated by the absence of the carbonyl stretching frequency of the aldehyde substituent, present $\mathrm{n}$ the starting material. Evidence for the formation of the Schiff base was given by the medium band observed at $1623 \mathrm{~cm}^{-1}$ due to the $\mathrm{v}(\mathrm{C}=\mathrm{N})$ [31]. The spectrum further displayed other bands which include bands at 1525 and $1340 \mathrm{~cm}^{-1}$, which were ascribed to the $v(\mathrm{C}-\mathrm{N})+\mathrm{v}(\mathrm{C}=\mathrm{C})$ and $\delta(\mathrm{C}-\mathrm{H})+\mathrm{v}(\mathrm{C}=\mathrm{N})$ frequencies 
respectively [31] [32] [33].

The UV-Vis spectrum of this ligand exhibited three absorption peaks at 232 and $324 \mathrm{~nm}$, which are assigned to $\mathrm{n} \rightarrow \sigma^{\star}, \pi \rightarrow \pi^{\star}$ and $\mathrm{n} \rightarrow \pi^{\star}$ transitions respectively of the major chromophores of the ligand. $-\mathrm{C}=\mathrm{N},-\mathrm{NH}_{2}$ and $-\mathrm{C}_{6} \mathrm{H}_{4}$ [32] [33].

The ${ }^{1} \mathrm{H}$ NMR spectrum of Ligand 3 in $\mathrm{CHCl}_{3}$ elicited a singlet at $\delta 0.03 \mathrm{ppm}$, this may be assigned to the amino protons [33] [42]. This signal thus suggests that one of the amino protons may be held in a shielded position and therefore it resonated at a significantly lower frequency [33]. A singlet observed at $1.21 \mathrm{ppm}$ was attributed to the methylene protons attached to the amino substituent $\left(\mathrm{CH}_{2} \mathrm{NH}_{2}\right)$. However, the second methylene proton bound to azomethine carbon resonated at $\delta 5.26 \mathrm{ppm}(\mathrm{q}, 2 \mathrm{H}$,$) , This appeared at higher frequency as a result of$ conjugation between the azomethine double bond and the lone pair of electrons of the nitrogen atom $\left(\mathrm{C}=\mathrm{NCH}_{2}\right)$ [32] [33]. The spectrum further revealed a singlet at $\delta 7.24 \mathrm{ppm}$, attributable to the azomethine protons $(\mathrm{HC}=\mathrm{N})$ [32] [33]. The aromatic protons came to resonance as a multiplet at $\delta 7.87-8.22 \mathrm{ppm}$. Another multiplet observed at $\delta 10.24-9.95 \mathrm{ppm}$ was ascribed to the deshielded amino proton [33]. Additionally, it is suggested that this signal was observed this up field as a result of hydrogen bonding [33].

The ${ }^{13} \mathrm{C}$ NMR of this compound exhibited a triplet at $\delta 77.01,77.23,77.44$ ppm which was due to the methylene carbons $\mathrm{CH}_{2} \mathrm{CH}_{2}$-[27] [32] [33]. A doublet observed at $\delta 140.21,140.00 \mathrm{ppm}$ was assigned to the azomethine carbon $(\mathrm{HC}=\mathrm{N})$. The aromatic carbons resonated as a multiplet $\delta 129.74-130.88$. A doublet observed at $\delta 181.77,191.67 \mathrm{ppm}$ was attributed to the carbon atom attached to the amino nitrogen [32] [33] [34] [35]. This observed chemical shift, therefore, corroborated probable intermolecular hydrogen bond in this substituent [27] [33].

\subsubsection{Ligand 4}

The infrared spectrum of Ligand 4 displayed a medium band at $3345 \mathrm{~cm}^{-1}$ which was assigned to $\mathrm{v}(\mathrm{N}-\mathrm{H})$ of an amino moiety. A sharp band was observed at 1618 $\mathrm{cm}^{-1}$ ascribable to the imine stretching frequency [31]. This, therefore, suggests the formation of a Schiff base. Additional stretching frequencies observed in this spectrum include 1516, $1326 \mathrm{~cm}^{-1}$ attributed to the $v(\mathrm{C}-\mathrm{N})+\mathrm{v}(\mathrm{C}=\mathrm{C})$ and $\delta(\mathrm{C}-\mathrm{H})+\mathrm{v}(\mathrm{C}=\mathrm{N})$ frequencies respectively, further supports the formation of the Schiff base [31].

The UV-Vis spectrum of this ligand exhibited three absorption peaks at 260 and $324 \mathrm{~nm}$, which are assigned to $\mathrm{n} \rightarrow \pi^{*}$ and $\pi \rightarrow \pi^{\star}$ transitions respectively [32] [33].

The proton NMR of Ligand 4 in $\mathrm{CHCl}_{3}$ showed two singlets at $\delta 0.03$ and 0.83 $\mathrm{ppm}$, this is suggestive of the shielding of an amino nitrogen [32]. The spectrum also revealed a doublet at $\delta 1.24$ and $1.21 \mathrm{ppm}$ which were assigned to methyl protons of the side chain $\left(\mathrm{CH}_{3}\right)$ [32] [33]. A singlet at $\delta 1.94 \mathrm{ppm}$ is ascribable to the methylene protons $\left(=\mathrm{N}-\mathrm{CH}_{2} \mathrm{CH}-\right)$. Another singlet observed at $\delta 3.45 \mathrm{ppm}$ 
was attributed to the methine proton bound to the amino substituent $\left(\mathrm{CH}-\mathrm{NH}_{2}\right)$ [32] [33] [34] [35]. Additionally, another singlet observed at $\delta 7.24 \mathrm{ppm}$ assigned to the azomethine proton, affirmed the formation of the Schiff base [32] [33]. A multiplet at $\delta 8.22 \mathrm{ppm}$ is consistent with aromatic protons. A sextet at 10.24, $10.12,10.10,10.08,10.06,9.95 \mathrm{ppm}$ indicates the proton of the amino moiety [32] [33]. This signal therefore, suggests that the $[1+2]$ condensation product of propane-1,2-diamine is not a closed macrocycle, consequently it may be inferred that ligand 4 is open-ended. The observed multiplicity is indicative of the non-planarity of the molecule. It also suggested that it is coupled to the carbon atom bearing the methyl side chain.

The ${ }^{13} \mathrm{C}$ NMR for Ligand 4 elicited a triplet at $\delta 77.01,77.23,77.44$ ppm assignable to the methine backbone of the molecule $-\mathrm{CH}_{2} \mathrm{CH}$-. [32] [33] A multiplet at about $\delta 130.48 \mathrm{ppm}$, was ascribed to aromatic carbons. A singlet at $\delta$ $140.21 \mathrm{ppm}$ is indicative of an azomethine carbon, the signal indicating the carbon bearing the amino substituent was observed at $\delta 191.66 \mathrm{ppm}$, suggestive of hydrogen bonding [33].

\subsection{Complexes of Ligands 3 and 4}

\subsubsection{Infrared}

The FTIR spectra for compounds $3 a, 3 b, 4 a$ and $\mathbf{4 b}$ showed the disappearance of $\mathrm{v}(\mathrm{C}=\mathrm{O})$, which supports the complete reaction of the aldehyde group with the amino substituent [31]. A striking feature of the spectra for compounds $3 \mathrm{a}, 3 \mathrm{~b}$, and $4 \mathrm{~b}$ is the observance of the $\mathrm{N}-\mathrm{H}$ stretching frequency of the $\mathrm{NH}_{2}$ moiety observed at 3201, 3150 and $3267 \mathrm{~cm}^{-1}$ respectively [31] [32] [33]. This suggests that one of the amino moiety of ethane-1,2-diamine and propane-1,2-diamine does not undergo condensation reaction towards the formation of an imine substituent and as such serves as an indication that macrocyclization occurred through the coordination sphere of the metal ion and that closure did not occur as a result of Schiff base formation of the second amino substituent of the diamine. This is corroborated by the presence of the imine stretching frequency in their spectra. Compound $4 \mathrm{a}$ however, did not exhibit this $v_{(\mathrm{NH} 2)}$ absorption, weak extended bands were observed in this region instead and this suggested $\mathrm{H}$-bonding [31] [32] [33]. This was further corroborated by the broad band at $2348 \mathrm{~cm}^{-1}$ [32] [33].

It should be noted that compounds $\mathbf{1 a}, \mathbf{1 b}, \mathbf{2} \mathbf{a}$ and $\mathbf{2 b}$ did not exhibit the N-H frequency stretching frequencies in their respective spectra. This therefore, lends corroboration to the closed macrocyclic structure for these complexes, contrary to that observed for compounds $3 \mathrm{a}, 3 \mathrm{~b}, \mathbf{4 a}$ and $\mathbf{4 b}$. In this case the $v(\mathrm{C}=\mathrm{N}+$ $\mathrm{CH}_{2}$ ) in both compounds $\mathbf{3 b}$ and $\mathbf{4} \mathbf{b}$ suggests that the methyl group assumed a cis-configuration for the complexes contrary to what was obtained for complexes $\mathbf{1 b}$ and $\mathbf{2 b}$. It is therefore suggested that it may lie towards the lower end of the macrocycle, attached to the lower end amino substituent. This may be ascribed to the electron donating property of the methyl substituent hence making the amino moiety more basic. On the other hand, the upper end amino substi- 
tuent is a tertiary one, with a double bond.

\subsubsection{Electronic Spectra and Magnetic Moment}

1) Compound 3a: The spectrum for the $\mathrm{Ni}(\mathrm{II})$ complex exhibited four bands. Two intense bands were observed in the ultraviolet region at 244 and $342 \mathrm{~nm}$. These are attributable $\pi \rightarrow \pi^{*}$ and $n \rightarrow \pi^{*}$ intraligand transition [32] [33]. Two broad bands were observed bands at 598 and $773 \mathrm{~nm}$ which were assigned to spin allowed $d-d$ transitions ${ }^{3} \mathrm{~A}_{2 g}(\mathrm{~F}) \rightarrow{ }^{3} \mathrm{~T}_{1 \mathrm{~g}}(\mathrm{~F})$ and ${ }^{3} \mathrm{~A}_{2 g}(\mathrm{~F}) \rightarrow{ }^{3} \mathrm{~T}_{1 \mathrm{~g}}(\mathrm{P})$, suggestive of an octahedral geometry [38]. The magnetic moment of $2.37 \mathrm{BM}$ indicated two unpaired electrons per nickel ion, further validates an octahedral geometry for the complex [38] [39].

2) Compound $3 \mathrm{~b}$ : The electronic spectrum of $3 \mathrm{~b}$ exhibited intraligand transition bands at 232 and $280 \mathrm{~nm} \pi \rightarrow \pi^{*}$ and $\mathrm{n} \rightarrow \pi^{*}$ intraligand transition [31] [32]. Additionally, in the visible region a well resolved band was observed at $634 \mathrm{~nm}$ and a weak band at $740 \mathrm{~nm}$. These were assigned to ${ }^{2} \mathrm{~B}_{1} \rightarrow{ }^{2} \mathrm{~A}_{1}$ and ${ }^{2} \mathrm{~B}_{1} \rightarrow{ }^{2} \mathrm{E}$ transitions, which suggested a square planar geometry [41]. This proposed geometry was corroborated by its magnetic moment of $2.47 \mathrm{BM}$, indicative of a square planar geometry. This is in agreement with that proposed by previous workers for similar compounds [41].

3) Compound 4a: The spectrum for the $\mathrm{Ni}(\mathrm{II})$ complex showed intraligand transition bands at 234 and $334 \mathrm{~nm}$, which correlates to $\pi \rightarrow \pi^{*}$ and $n \rightarrow \pi^{*}$ intraligand transition. $d-d$ bands at $540,670 \mathrm{~nm}$ which were assigned to spin allowed transitions of ${ }^{3} \mathrm{~A}_{2}(\mathrm{~F}) \rightarrow{ }^{3} \mathrm{~T}_{1}(\mathrm{~F})$ and ${ }^{3} \mathrm{~A}_{2}(\mathrm{~F}) \rightarrow{ }^{3} \mathrm{~T}_{1}(\mathrm{P})$ [36] [37]. The magnetic moment of $0.83 \mathrm{BM}$ indicated two unpaired electrons per nickel ion, further validates a square planar geometry [40].

4) Compound $4 \mathrm{~b}$ : The ultraviolet region of this spectrum elicited two bands, a medium and an intense band, at 275 and $346 \mathrm{~nm}$. Assigned to $\pi \rightarrow \pi^{*}$ and $n \rightarrow \pi^{*}$ intraligand transitions [31] [32]. On the other hand, the visible region of the spectrum for this compound displayed two broad bands at 668 and $720 \mathrm{~nm}$, which were ascribed to ${ }^{2} \mathrm{~B}_{1} \rightarrow{ }^{2} \mathrm{~A}_{1}$ and ${ }^{2} \mathrm{~B}_{1} \rightarrow{ }^{2} \mathrm{E}_{1} d-d$ transitions [36] [37]. Its magnetic moment of $2.43 \mathrm{BM}$ is indicative of a square planar geometry with possible antiferromagnetism [41]. However, a square planar geometry is proposed based on the molecular ion obtained from its mass spectrum [41].

It has been reported that the composition of the product obtained by the reaction of dicarbonyl compounds with diamines is determined by several factors. The target product can be prepared in good yield by varying the concentration and the ratio of the reagent, the nature of the solvents, the temperature and the catalyst [15]. Furthermore, intermolecular reactions giving oligomers are generally suppressed using high dilution conditions and stoichiometric amount of the components [15]. These factors were to attain our target condensation products.

A non-template approach was used to obtain the $[2+2]$ condensation products Ligands 1 and 2 (Figure 2 and Figure 3). The method described by Grupta and Mukherjee (1997) was used to obtain Ligand 1 using acetonitrile as solvent [27]. However, for the synthesis of Ligand 2 a deep yellow product was obtained 
<smiles>O=Cc1ccc(C=O)cc1</smiles>

a<smiles>NCCN</smiles>

b<smiles>Cc1ccc(/C=N\CC/N=C\c2ccc(/C=N\CC/N=C\c3ccc(I)cc3)cc2)cc1</smiles>

\section{Ligand 1}

Figure 2. Schematic diagram for the synthesis of Ligand 1.<smiles>CC(N)CN</smiles>

a c<smiles>C=NC(C)CN=Cc1ccc(C=NC(C)CN=Cc2ccc(C=NC(C)C)cc2)cc1</smiles>

Ligand 2

Figure 3. Schematic diagram for the synthesis of Ligand 2.

that was partially soluble in organic solvents. Hence absolute ethanol was used at low concentration and at high dilution to avoid the formation of oligomers which were gelatinous in nature. On the other hand, a template approach was implemented to attain Ligands 3 and 4 in reasonable yields (Figure 4 and Figure 5 ). This was found to be essential to form the ligands since otherwise only a polymeric mixture, partially soluble in DMSO was recovered via direct approach. The ligands were prepared from the reaction of benzene-1,4-dicarboxaldehyde 


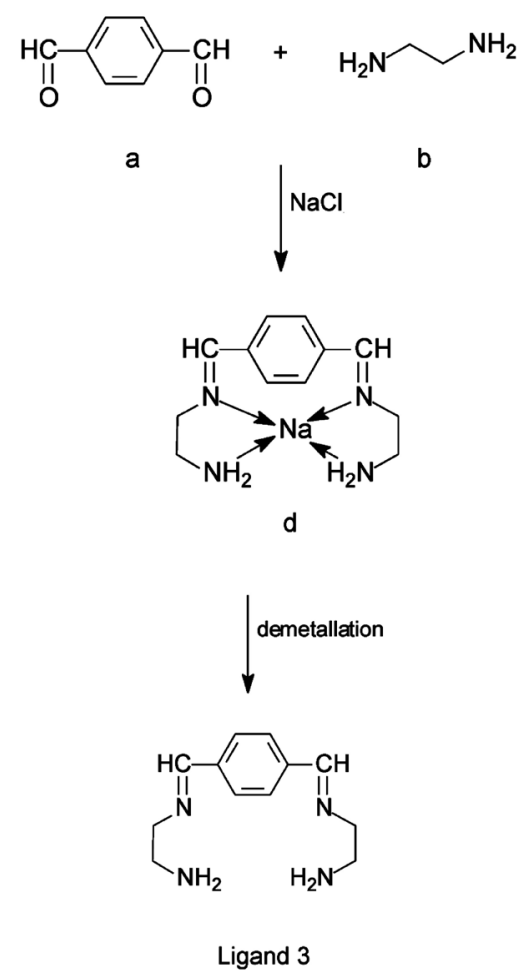

Figure 4. Schematic diagram for the synthesis of Ligand 3.<smiles>CC(N)CN</smiles>

a

c

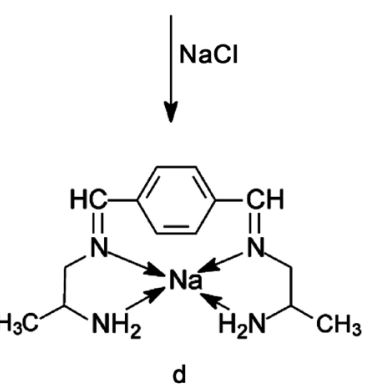

d<smiles>CC(N)CN=Cc1ccc(C=NCC(C)N)cc1</smiles>

Ligand 4

Figure 5. Schematic diagram for the synthesis of Ligand 4. 
and ethane-1,2-diamine and propane-1,2-diamine in the ratio 1:2, respectively. This was followed by demetallation to give Ligands 3 and 4 [15] [16] [17].

Based on the results obtained it was therefore suggested that the $[2+2]$ condensation reaction of benzene-1,4-dicarboxaldehyde and ethane-1,2-diamine and propane-1,2-diamine afforded closed macrocycles, Ligands 1 and 2 respectively. Structurally this may be depicted as shown in Figure 2 and Figure 3. On the other hand the $[1+2]$ condensation liner products of the benzene-1,4-dicarboxaldehyde and ethane-1,2-diamine and propane-1,2-diamine were obtained via template synthesis followed by demetallation to give Ligands 3 and 4 (Figure 4 and Figure 5). This is because the template agent enables the mutual orientation favourable for $\mathrm{C}=\mathrm{N}$ formation to produce rigidly controlled structures. The results obtained suggested that these ligands are open ended, linear molecules. Both Ligands 1 and 2 coordinated to $\mathrm{Ni}(\mathrm{II})$ and $\mathrm{Cu}(\mathrm{II})$ via the four azomethine nitrogens, as such they both acted as $N, N, N^{\prime}, N^{\prime}$ tetradentate ligands. From the results obtained we propose octahedral geometry for compounds $1 \mathrm{a}$ and $\mathbf{1 b}$ suggesting coordination with additional two molecules of ethanol from the solvent (Figure 6). However, a square planar geometry is proposed for $\mathbf{2 b}$ and $\mathbf{2 a}$ (Figure 7). For the case of $2 \mathrm{a}$ and $\mathbf{2 b}$ we propose that the $-\mathrm{CHCH}_{3}$ are trans to each other. For the $[1+2]$ condensation complexes, we propose that macrocyclic closure occurred in the coordination sphere of the metal ions. Square planar geometry is proposed for $\mathbf{3 b}, \mathbf{4 a}$ and $\mathbf{4 b}$ (Figure 8 ) and octahedral for $\mathbf{3 a}$ (Figure 9). The reason for this is not readily evident but we suggest that the methyl appendage towards the end of the macrocycle may assist in restricting and ensuring that the structure is more defined in the case of compounds $4 \mathrm{a}$ and $4 \mathrm{~b}$ (Figure 10). However, in the case of $3 a$ and $3 b$, the size of the metal ions may be a factor in the respective geometry assumed by each compound. We also propose that in the case of complexes $4 \mathrm{a}$ and $4 \mathrm{~b}$ the $-\mathrm{CHCH}_{3}$ are cis to each. This was suggested by the results obtained from the infrared and NMR spectroscopic analyses.

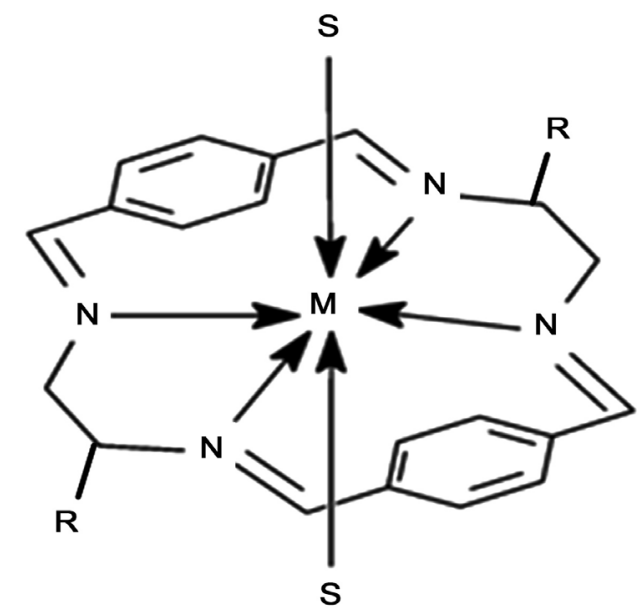

Figure 6. Pictorial representation for compound $\mathbf{1 a}$ and $\mathbf{1 b}$; where $\mathrm{R}=\mathrm{H}$ : $1 \mathrm{a} \mathrm{M}=\mathrm{Ni}$ and $\mathbf{1 b} \mathrm{M}=\mathrm{Cu}$. 


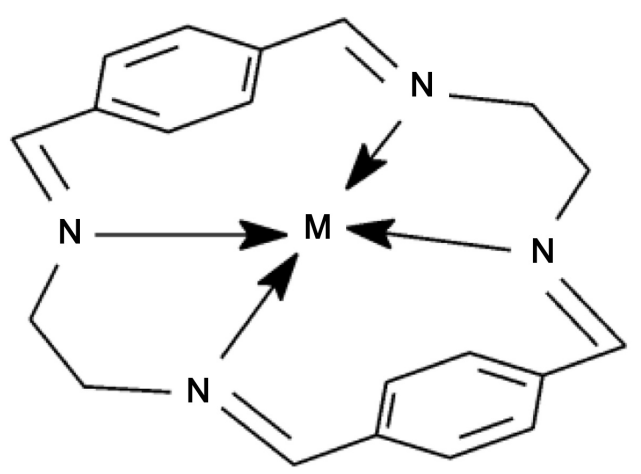

Figure 7. Pictorial representation for compound $2 \mathrm{a}$ and $2 \mathrm{~b}$.

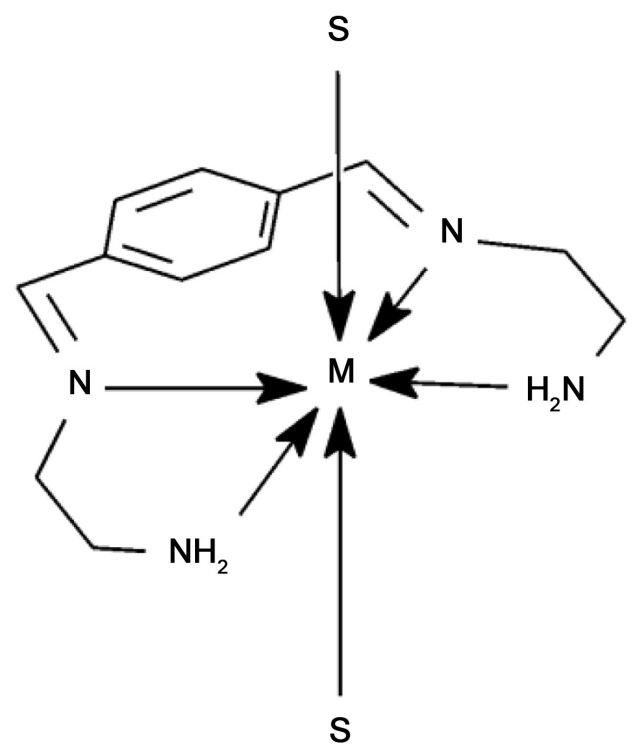

Figure 8. Pictorial representation for compound $3 a$.

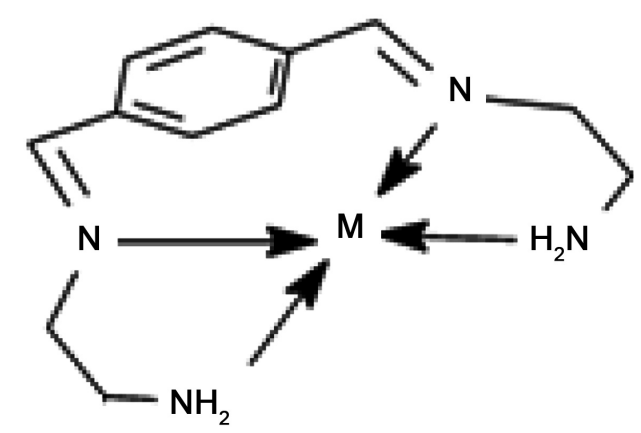

Figure 9. Pictorial representation for compound $3 \mathrm{~b}$.

\subsection{Antimicrobial Activity}

The ligands and the synthesized complexes were evaluated for their antimicrobial activity against five Gram-positive bacteria, three Gram-negative bacteria and 


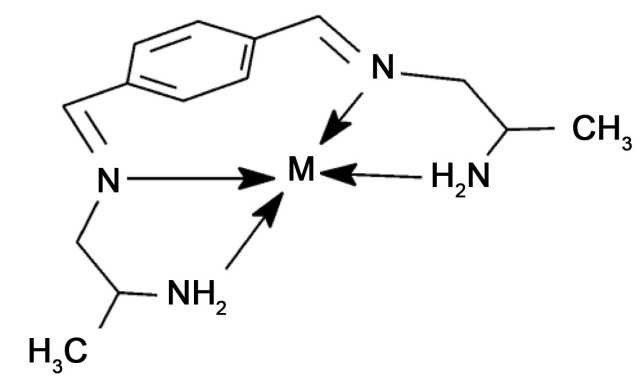

Figure 10. Pictorial representation for compound $4 \mathrm{a}$ and $4 \mathrm{~b}$.

two fungi. The results obtained are presented in Table 1 . The ligands did not exhibit significant activity Ligand 2 exhibited the best activity among the ligands. Generally, the compounds with the methyl side chain indicated better activity in most cases in relation with its respective corresponding counterparts without methyl side chain, with the exception of compound $\mathbf{1 b}$. Compound $\mathbf{1 b}$ exhibited better activity against Clostridium and B. subtilis 12 . The established antimicrobial activity of copper was evident in the results obtained with the compounds with copper(II) ion coordinated eliciting better activity with the $[1+2]$ condensation complexes [43]. On the other hand, for the closed macrocyclic complexes the $\mathrm{Ni}(\mathrm{II})$ complexes exhibited better activity in most cases. The results obtained therefore suggest that the mode of antimicrobial activity of the complexes is probably ion transfer. This is in agreement with earlier reports of the antimicrobial activity of macrocycles [44]. Generally, the [2+2] macrocyclic complexes indicated better activity when compared with their $[1+2]$ counterparts with the exception of compound $\mathbf{4 b}$, which elicited significantly better activity $(\mathrm{P}<0.05)$ against $E$. coli and $K$. pneumonia. This increase in antibacterial activity can be explained based on Overtone's concept and Tweedy's chelation theory.

The lipid membrane that surrounds the cell favours the passage of lipid-soluble materials. As such this may be a factor for antimicrobial activity. On coordination, the polarity of the metal ion is reduced to a greater extent due to the overlap of the ligand orbitals and partial sharing of the positive charge of the metal ion with the donor groups. Furthermore, it increases the delocalization of $\pi$ electrons over the whole chelate ring and hence enhances the liposolubility of the complexes. This increased liposolubility enhances the penetration of the complexes into the lipid membrane and the complex interferes in the normal activities of the bacteria [45] [46] [47] [48].

\subsection{Mole Ratio of the Metal Ions to the Ligands in the Formation of the Complexes}

The absorbance obtained was plotted against the mole ratio of the metal to the ligand used in the complex formation. A parabolic graph was obtained for all four ligands and for both metal ions (Figures 11-13). Maximum absorbance 
T. Aiyelabola et al.

Table 1. Result of zone of antimicrobial inhibition ( $\mathrm{mm}$ ) for the ligands and complexes.

\begin{tabular}{|c|c|c|c|c|c|c|c|c|c|c|c|c|c|}
\hline Organism & 1 & 2 & 3 & 4 & la & $1 b$ & $2 \mathrm{a}$ & $2 \mathrm{~b}$ & $3 a$ & $3 b$ & $4 \mathrm{a}$ & $4 \mathrm{~b}$ & $\mathrm{C}$ \\
\hline S. aureus & - & - & - & - & 06 & 14 & 08 & 09 & 02 & 01 & - & 10 & 44 \\
\hline S. epidermidis & - & - & - & 06 & - & 05 & 04 & 07 & - & 07 & 04 & 06 & 34 \\
\hline B. subtilis 12 & - & - & - & - & 07 & - & - & 04 & - & 04 & - & 08 & 34 \\
\hline B. subtilis 82 & 04 & - & - & - & 06 & 06 & - & - & 07 & 10 & 06 & - & 29 \\
\hline Clostridium & - & - & - & - & 05 & 12 & 07 & 06 & - & - & - & - & 34 \\
\hline$K \cdot$ pneumonia & - & - & - & - & 11 & 07 & - & 07 & - & $=$ & - & 06 & 34 \\
\hline$P$. aeruginosa & - & - & - & - & 06 & 04 & - & - & 09 & 06 & 10 & - & 39 \\
\hline E. coli & - & - & - & - & - & - & 05 & - & - & - & 06 & 11 & 33 \\
\hline C. albicans & - & - & - & - & - & - & - & - & 06 & - & 04 & - & 36 \\
\hline C. pseudotropicalis & - & - & - & - & - & - & - & - & - & - & - & 12 & 36 \\
\hline
\end{tabular}

Where $\mathrm{C}=$ imipenem and chlorhexidine for bacteria and fungi respectively.

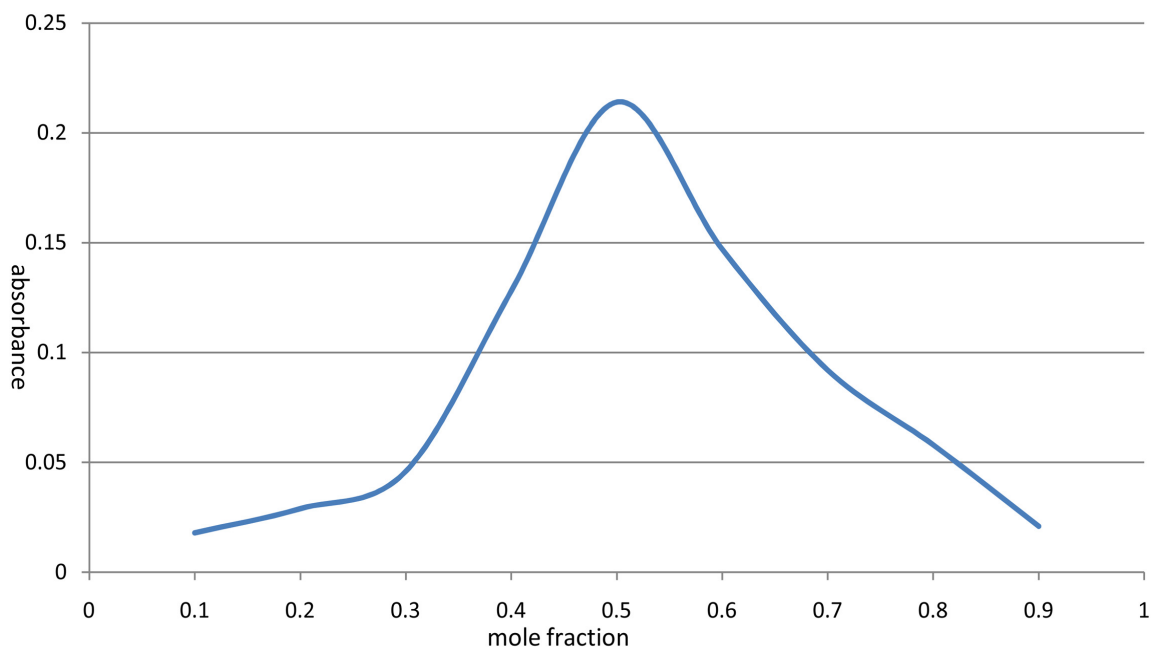

Figure 11. Plot of absorbance against mole fraction for compound 2a.

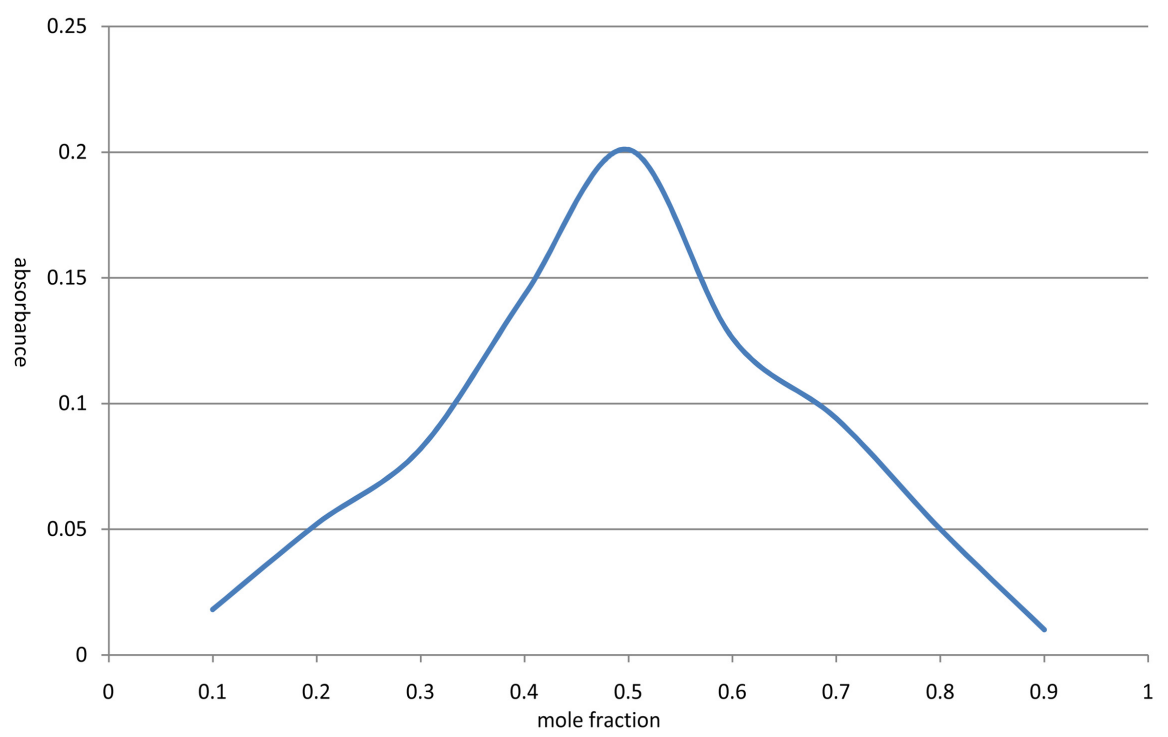

Figure 12. Plot of absorbance against mole fraction for compound 3a. 


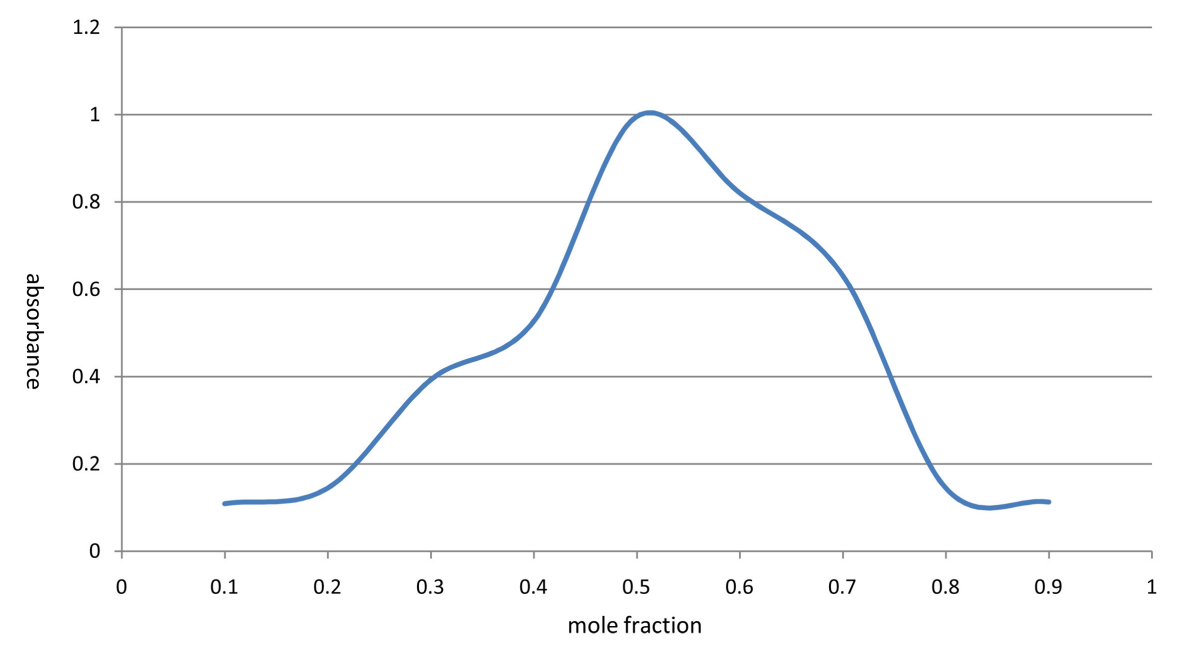

Figure 13. Plot of absorbance against mole fraction for compound $3 \mathbf{b}$.

value from the graphs was obtained and corresponded to metal ligand ratio in the complex of 5:5 (Table 2 and Table 3). The mole ratio with respect to both metal ions indicated 0.5 , this indicates the formulation of 1:1 complex for both nickel and copper(II) ions with Ligands 1, 2, 3 and 4 . This implies that the ligands and metal ions reacted in the ratio (1:1) which are in agreement with the proposed stoichiometry.

\subsection{Solvent Extraction Studies}

In this research liquid-liquid extraction experiments were performed to examine the extractability and efficiency of extraction of certain metal ions by Ligands 1-4 at $\mathrm{pH} 4.5$ and 10. The results obtained indicated that the ligands significantly extracted $\mathrm{Cd}^{2+}, \mathrm{Zn}^{2+}$ and $\mathrm{Pb}^{2+}$. This indicates the ability of polyaza macrocyclic as inorganic cation receptors. The cyclic arrangement of a large number of donor atoms and the flexibility of these ligands make them good hosts for ion. Therefore, it suggests their potential to separate and precipitate toxic metal ions. Mostly for the metal ions the highest extractability was obtained in the basic medium (Table 4 and Table 5). This suggests that the donor atoms were more readily available in basic medium. An exception to this was $\mathrm{Pb}^{2+}$ which had its highest extraction in the acidic medium with Ligand 3. The reason for this is not readily evident; however, we suggest its size may make it more suited for the core in this medium. The highest extractability of $\mathrm{Cd}^{2+}$ among the metal ions was achieved by Ligand 4 at $\mathrm{pH} 10$. On the other hand, Ligand 1 was the most efficient in the extraction of $\mathrm{Zn}^{2+}$. In the case of $\mathrm{Pb}^{2+}$ maximum extractability was attained with Ligand $3 \mathrm{a}$ straight chain molecule. This suggests that the cavity size and the size of the metal ion to be extracted are functions of the ability of the ligand to extract the metal ions. More importantly this alludes to the fact that the flexibility of open ended ligands is a determining factor in their ability to chelate effectively [37]. Interestingly in the case of $\mathrm{Cd}^{2+}$ ligands with the side methyl substituent, Ligands 2 and 4, were more effective in the extraction of 
T. Aiyelabola et al.

Table 2. Experimental data for the extraction of $\mathrm{Ni}(\mathrm{II})$ and $\mathrm{Cu}(\mathrm{II})$ using Ligands $\mathbf{1}$ and 2.

\begin{tabular}{ccccccc}
\hline S/N & M:L & $\begin{array}{c}\text { Mole } \\
\text { Fraction of the } \\
\text { reactants }\end{array}$ & $\begin{array}{c}\mathrm{Ni} \\
\text { Absorbance } \\
\text { Ligand 1 }\end{array}$ & $\begin{array}{c}\mathrm{Cu} \\
\text { Absorbance }\end{array}$ & $\begin{array}{c}\mathrm{Ni} \\
\text { Absorbance } \\
\text { Ligand 2 }\end{array}$ & $\begin{array}{c}\mathrm{Cu} \\
\text { Absorbance }\end{array}$ \\
\hline 1 & $1: 9$ & 0.9 & 0.036 & 0.009 & 0.021 & 0.149 \\
2 & $2: 8$ & 0.8 & 0.050 & 0.036 & 0.058 & 0.210 \\
3 & $3: 7$ & 0.7 & 0.091 & 0.054 & 0.092 & 0.471 \\
4 & $4: 6$ & 0.6 & 0.104 & 0.262 & 0.147 & 0.795 \\
5 & $5: 5$ & 0.5 & 0.106 & 0.483 & 0.214 & 1.094 \\
6 & $6: 4$ & 0.4 & 0.008 & 0.235 & 0.128 & 0.461 \\
7 & $7: 3$ & 0.3 & 0.005 & 0.156 & 0.046 & 0.243 \\
9 & $8: 2$ & 0.2 & 0.003 & 0.124 & 0.029 & 0.145 \\
\hline
\end{tabular}

Table 3. Experimental data for the extraction of $\mathrm{Ni}(\mathrm{II})$ and $\mathrm{Cu}(\mathrm{II})$ using Ligands 3 and 4.

\begin{tabular}{ccccccc}
\hline S/N & M:L & $\begin{array}{c}\text { Mole } \\
\text { Fraction }\end{array}$ & $\begin{array}{c}\mathrm{Ni} \\
\text { Absorbance } \\
\text { Ligand 3 }\end{array}$ & $\begin{array}{c}\mathrm{Cu} \\
\text { Absorbance }\end{array}$ & $\begin{array}{c}\mathrm{Ni} \\
\text { Absorbance } \\
\text { Ligand 4 }\end{array}$ & $\begin{array}{c}\mathrm{Cu} \\
\text { Absorbance }\end{array}$ \\
\hline 1 & $1: 9$ & 0.9 & 0.010 & 0.113 & 0.049 & 0.160 \\
2 & $2: 8$ & 0.8 & 0.050 & 0.145 & 0.065 & 0.150 \\
3 & $3: 7$ & 0.7 & 0.094 & 0.632 & 0.096 & 0.302 \\
4 & $4: 6$ & 0.6 & 0.126 & 0.821 & 0.084 & 0.705 \\
5 & $5: 5$ & 0.5 & 0.201 & 0.996 & 0.165 & 0.830 \\
7 & $6: 4$ & 0.4 & 0.143 & 0.527 & 0.084 & 0.520 \\
9 & $7: 3$ & 0.3 & 0.082 & 0.393 & 0.030 & 0.418 \\
\hline
\end{tabular}

Table 4. Extraction efficiency of the metal ions at $\mathrm{pH} 4.5$.

\begin{tabular}{cccccccc}
\hline Ligand & $E \%$ & $\mathrm{Cd}^{2+} \mathrm{R} \%$ & $E \%$ & $\mathrm{Zn}^{2+} \mathrm{R} \%$ & & $E \%$ & $\mathrm{~Pb}^{2+} \mathrm{R}^{2}$ \\
\hline 1 & 75.23 & 79.43 & 94.25 & 95.56 & 84.68 & 94.32 \\
2 & 66.06 & 72.90 & 53.02 & 79.29 & 98.02 & 99.19 \\
3 & 83.16 & 84.95 & 70.49 & 86.74 & 98.01 & 99.25 \\
4 & 88.11 & 89.14 & 73.94 & 88.01 & 86.24 & 94.79 \\
\hline
\end{tabular}

Table 5. Extraction efficiency of the metal ions at $\mathrm{pH} 10$.

\begin{tabular}{|c|c|c|c|c|c|c|}
\hline Ligand & $E \%$ & $\mathrm{Cd}^{2+} \mathrm{R} \%$ & $E \%$ & $\mathrm{Zn}^{2+} \mathrm{R} \%$ & $E \%$ & $\mathrm{~Pb}^{2+} \mathrm{R} \%$ \\
\hline 1 & 96.50 & 96.55 & 93.20 & 96.94 & 75.40 & 78.12 \\
\hline 2 & 95.09 & 97.44 & 70.49 & 86.18 & 92.32 & 97.73 \\
\hline 3 & 96.87 & 96.97 & 93.62 & 95.31 & 97.31 & 97.26 \\
\hline 4 & 99.89 & 99.88 & 58.27 & 81.49 & 78.06 & 80.41 \\
\hline
\end{tabular}

$\mathrm{Cd}^{2+}$ both in the acidic and basic medium in comparison with their counterparts, Ligands 1 and 3. Additionally for this metal ion, macrocyclic Ligands 1 and 2 
indicated better activity in both acidic and basic medium relative to the open ended Ligands 3 and 4. It would have been expected that $\mathrm{Zn}^{2+}$ had better extractability in comparison with the other two cations $\mathrm{Cd}^{2+}$ and $\mathrm{Pb}^{2+}$ as a result of its smaller size. Surprisingly this is not the case from the results obtained. Therefore, as a consequence of the results obtained it is suggested that these factors: the size of the core, the size of the metal ion to be incorporated, peripheral substituent, flexibility of linear ligands and the reaction medium determine the ability of these ligands in extraction of metal ions in solution [21] [42] [49] [50]. It should be noted that in the case of lead(II) ion, it has an electronic configuration of $[\mathrm{Xe}] 4 \mathrm{f}^{14} 5 \mathrm{~d}^{10} 6 \mathrm{~s}^{2}$, with penultimate and anti-penultimate shells inclusive of $4 f^{4}$ and $5 d^{10}$, indicative of the effects of lanthanide contraction, which may therefore be reflected in its reactivity [36] [37].

\section{Conclusion}

It was concluded that condensation products of benzene-1,4-dicarboxaldehyde with two diamines: ethane-1,2-diamine and propane-1,2-diamine may yield linear or macrocyclic Schiff. The desired target product was obtained in good yield by varying the concentration and the ratio of the reagent, the nature of the solvents, the temperature and the catalyst. The results obtained also indicated that chelation may enhance the antimicrobial activity of some of the ligands. It was further concluded that the ability to extract metal ions in solutions by these ligands is a function of the size of its core, the size of the metal ion to be incorporated, peripheral substituents and the reaction medium.

\section{Conflicts of Interest}

The authors declare no conflicts of interest regarding the publication of this paper.

\section{References}

[1] Kumar, G., Kumar, D., Devi, S., Johari, R. and Singh, C.P. (2012) Synthesis, Spectral Characterization and Antimicrobial Evaluation of Schiff Base $\mathrm{Cr}$ (III), Mn(III) and Fe(III) Macrocyclic Complexes. European Journal of Medicinal Chemistry, 52, 269-274. https://doi.org/10.1016/j.ejmech.2012.03.025

[2] Sivasankaran, M.N., Arish, D. and Johnson, J. (2016) Synthesis, Characterization and Biological Studies on Some Metal Complexes with Schiff Base Ligand Containing Pyrazolone Moiety. Journal of Saudi Chemical Society, 20, S591-S598. https://doi.org/10.1016/j.jscs.2013.04.007

[3] Malik, M.A., Dar, O.A., Gull, P., Wani, M.Y. and Hashmi, A.A. (2018) Heterocyclic Schiff Base Transition Metal Complexes in Antimicrobial and Anticancer Chemotherapy. Medchemcomm, 9, 409-436. https://doi.org/10.1039/C7MD00526A

[4] Mohamed, G.G. and Abd El-Wahab, Z.H. (2005) Mixed Ligand Complexes of Bis(phenylimine) Schiff Base Ligands Incorporating Pyridinium Moiety Synthesis, Characterization and Antibacterial Activity. Spectrochimica Acta, Part A: Molecular and Biomolecular Spectroscopy, 61, 1059-1068.

https://doi.org/10.1016/j.saa.2004.06.021 
[5] Shebi, M., Khalid, S.M.E., Ahmed, S.A. and Medien, H.A.A. (2010) Synthesis, Spectroscopic Characterization and Antimicrobial Activity of Mono-, Bi- and Tri-Nuclear Metal Complexes of a New Schiff Base Ligand. Journal of Molecular Structure, 980, 39-50. https://doi.org/10.1016/j.molstruc.2010.06.034

[6] Kumar, G., Kumar, D., Devi, S., Johari, R. and Singh, C.P. (2010) Synthesis, Spectral Characterization and Antimicrobial Evaluation of Schiff Base $\mathrm{Cu}(\mathrm{II}), \mathrm{Ni}(\mathrm{II})$ and Co(II) Complexes. European Journal of Medicinal Chemistry, 5, 3056-3062. https://doi.org/10.1016/j.ejmech.2010.03.036

[7] Kulkarni, A. Patil, S.A. and Badami, P.S. (2009) Synthesis, Characterization, DNA Cleavage and in Vitro Antimicrobial Studies of La(III), Th(IV) and VO(IV) Complexes with Schiff Bases of Coumarin Derivatives. European Journal of Medicinal Chemistry, 44, 2904-2912. https://doi.org/10.1016/j.ejmech.2008.12.012

[8] Bagihalli, G.B., Avaji, P.G., Patil, S.A. and Badami, P.S. (2008) Synthesis, Spectral Characterization, In Vitro Antibacterial, Antifungal and Cytotoxic Activities of $\mathrm{Co}(\mathrm{II}), \mathrm{Ni}(\mathrm{II})$ and $\mathrm{Cu}(\mathrm{II})$ Complexes with 1,2,4-triazole Schiff Bases. European Journal of Medicinal Chemistry, 43, 2639-2649. https://doi.org/10.1016/j.ejmech.2008.02.013

[9] Singh, K., Barwa, M.S. and Tyagi, P. (2007) Synthesis and Characterization of Cobalt(II), Nickel(II), Copper(II) and Zinc(II) Complexes with Schiff Base Derived from 4-Amino-3-mercapto-6-methyl-5-oxo-1,2,4-triazine. European Journal of Medicinal Chemistry, 42, 394-402. https://doi.org/10.1016/j.ejmech.2006.10.016

[10] Ramesh, R. and Maheswaran, S. (2003) Synthesis, Spectra, Dioxygen Affinity and Antifungal Activity of $\mathrm{Ru}(\mathrm{III})$ Schiff Base Complexes. Journal of Inorganic Biochemistry, 96, 457-462. https://doi.org/10.1016/S0162-0134(03)00237-X

[11] Vanc, J., et al. (2008) Synthesis, Structural Characterization, Antiradical and Antidiabetic Activities of Copper(II) and Zinc(II) Schiff Base Complexes Derived from Salicylaldehyde and $\beta$-Alanine. Journal of Inorganic Biochemistry, 102, 595-605. https://doi.org/10.1016/j.jinorgbio.2007.10.003

[12] Silveira, V.C., Luz, J.S., et al. (2008) Double-Strand DNA Cleavage Induced by Oxindole-Schiff Base Copper(II) Complexes with Potential Antitumor Activity. Journal of Inorganic Biochemistry, 102, 1090-1103. https://doi.org/10.1016/j.jinorgbio.2007.12.033

[13] Galal, S.A., Hegab, K.H., Kassab, A.S., Rodriguez, M.L., et al. (2009)) New Transition Metal Ion Complexes with Benzimidazole-5-Carboxylic Acid Hydrazides with Antitumor Activity. European Journal of Medicinal Chemistry, 44, 1500-1508. https://doi.org/10.1016/j.ejmech.2008.07.013

[14] Zhong, X., Yi, J., Sun, J., Wei, H.L., Liu, W.S. and Yu, K.B. (2006) Synthesis and Crystal Structure of Some Transition Metal Complexes with a Novel Bis-Schiff Base Ligand and Their Antitumor Activities. European Journal of Medicinal Chemistry, 41, 1090-1092. https://doi.org/10.1016/j.ejmech.2006.05.009

[15] Borisova, N.E., Borisova, R.N.E., Reshetova, M.D. and Ustynyuk, Y.A. (2007) Metal-Free Methods in the Synthesis of Macrocyclic Schiff Bases. Chemical Reviews, 107, 46-79. https://doi.org/10.1021/cr0683616

[16] Radecka-Paryzek, W., Patroniak, V. and Lisowski, J. (2005) Metal Complexes of Polyaza and Polyoxaaza Schiff Base Macrocycles. Coordination Chemistry Reviews, 249, 2156-2175. https://doi.org/10.1016/j.ccr.2005.02.021

[17] Vilar, N.G.R. (2006) Anions as Templates in Coordination and Supramolecular Chemistry. Coordination Chemistry Reviews, 250, 3161-3189. https://doi.org/10.1016/j.ccr.2006.05.016 
[18] Memon, S.Q., Memon, N., Mallah, A., Soomro, R. and Khuhawar, M.Y. (2014) Schiff Bases as Chelating Reagents for Metal Ions Analysis. Current Analytical Chemistry, 10, 393-417. https://doi.org/10.2174/157341101003140521113731

[19] Acosta-Rueda, L., Delgado-Pinar, E., Pitarch-Jarque, J., Rodríguez, A., Blasco, S., González, J., Basallote, M.G. and García-España, E. (2015) Correlation between the Molecular Structure and the Kinetics of Decomposition of Azamacrocyclic Copper(II) Complexes. Dalton Transactions, 44, 8255.

https://doi.org/10.1039/C5DT00408I

[20] Taylor, M.K., Reglinski, J. and Wallace, D. (2004) Coordination Geometry of Tetradentate Schiffs Base Nickel Complexes: The Effects of Donors, Backbone Length and Hydrogenation. Polyhedron, 23, 3201-3209.

https://doi.org/10.1016/j.poly.2004.10.002

[21] Tuncer, S., Koca, A., Gül, A. and Avcrata, U. (2012) Synthesis, Characterization, Electrochemistry and Spectroelectrochemistry of Novel Soluble Porphyrazines Bearing Unsaturated Functional Groups. Dyes and Pigments, 92, 610-618. https://doi.org/10.1016/j.dyepig.2011.05.023

[22] Ertul, S. and Azak, H. (2011) Effect of Macrocyclic Lactam Receptors on Extraction of Heavy Metals and Chomate Anions. Journal of Inclusion Phenomena and Macrocyclic Chemistry, 70, 153-159. https://doi.org/10.1007/s10847-010-9880-7

[23] Micheal, C.A., Dominey-Howes, D. and Labbate (2014) The Antimicrobial Resistance Crisis: Causes, Consequences and Management. Frontiers in Public Health Infectious Diseases, 2, 1-8. https://doi.org/10.3389/fpubh.2014.00145

[24] Kumar, A., Vashistha, V.K., Tevatia, P. and Singh, R. (2017) Electrochemical Studies of DNA Interaction and Antimicrobial Activities of $\mathrm{Mn}^{\mathrm{II}}, \mathrm{Fe}^{\mathrm{III}}, \mathrm{Co}^{\mathrm{II}}$ and $\mathrm{Ni}^{\mathrm{II}}$ Schiff Base Tetraazamacrocyclic Complexes. Spectrochimica Acta Part A: Molecular and Biomolecular Spectroscopy, 176, 123-133. https://doi.org/10.1016/j.saa.2016.12.011

[25] Chaemiso, T.D. and Nefo, T. (2019) Removal Methods of Heavy Metals from Laboratory Wastewater. Journal of Natural Sciences Research, 9, 16-42.

[26] Hirayama, N., Taga, J., Oshima, S. and Honjo, T. (2002) Sulfonamide-Type Di-Schiff Base Ligands as Chelate Extraction Reagents for Divalent Metal Cations. Analytica Chimica Acta, 466, 295-301. https://doi.org/10.1016/S0003-2670(02)00573-1

[27] Gupta, R. and Mukherjee, R. (1997) A New Tyrosinase Model Systems: Formation of a Phenoxy- and Hydroy-Bridged Copper(II) Complex with Partial Hydrolysis of a Tetraaza Macrocyclic Schiff Base Ligand. Inorganic Chimica Acta, 263, 133-137. https://doi.org/10.1016/S0020-1693(97)05655-7

[28] Aiyelabola, T., Ojo, I. and Akinkunmi, O. (2012) Structural and Antimicrobial Studies of Coordination Compounds of Phenylalanine and Glycine. International Journal of Chemistry, 4, 49-59. https://doi.org/10.5539/ijc.v4n2p49

[29] Renny, J.S., Tomasevich, L.L., Tallmadge, E.H. and Collum, D.B. (2013) Method of Continuous Variations: Applications of Job Plots to the Study of Molecular Association in Organometallic Chemistry. Angewandte Chemie International Edition, 11, 11998-12013. https://doi.org/10.1002/anie.201304157

[30] Zoubi, W.A. and Chebani, K. (2011) Solvent Extraction of Chromium and Copper Using Schiff Base Derived from Terephthalaldehyde and 5-Amino-2-methoxy-phenol. Arabian Journal of Chemistry, 9, 526-531. https://doi.org/10.1016/j.arabjc.2011.06.023

[31] Nakamoto, K. (2009) Infrared and Raman Spectroscopy of Inorganic and Coordination Compounds: Applications in Coordination, Organometallics and Bioinor- 
ganic Chemistry. 6th Edition, John Wiley and Sons, New York, 67-69.

[32] Pavia, G. and Lampman, G.K. (2001) Introduction to Spectroscopy, a Guide for Students of Organic Chemistry. 3rd Edition, Brooks and Cole, United States of America, 22-368.

[33] Kemp, W. (1999) Organic Spectroscopy. 3rd Edition, Macmillan, Hong Kong, 19-98.

[34] Saunders, J.K.M. and Hunters, B.K. (1992) Modern NMR Spectroscopy a Guide for Chemists. 2nd Edition, Oxford University Press, London, 34-95.

[35] Gunther, H. (1995) NMR Spectroscopy, Basic Principles, Concepts and Applications in Chemistry. 2nd Edition, John Wiley and Sons, New York, 1-78.

[36] Miessler, G.L. and Tarr, D.A. (1999) Inorganic Chemistry. Pearson Prentice Hall, New York, 315-316.

[37] Greenwood, N.N. and Earnshaw, A. (1997) Chemistry of the Elements. 2nd Edition, Butterworth-Heinemann, Hong Kong, 1060-1090, 1290-1326.

[38] Osowole, A. (2011) Synthesis, Characterization and Magnetic and Thermal Studies on Some Metal(II) Thiophenyl Schiff Base Complexes. International Journal of Inorganic Chemistry, 2011, Article ID: 650186. https://doi.org/10.1155/2011/650186

[39] Osowole, A.A., Kolawole, O.E. and Fagade, S. (2008) Synthesis Physicochemical and Biological Properties of Nickel(II), Copper(II) and Zinc(II) Complexes of an Unsymmetrical Tetradentate Schiff Base and Adducts with 2,2'-Dipyridine and 1,10-Phenantroline. Journal of Coordination Chemistry, 61, 1046-1055. https://doi.org/10.1080/00958970701482446

[40] Osowole, A.A. (2008) A Studies on Some VO(IV), Ni(II) and Cu(II) Complexes of Non-Symmetrical Tetradentate Schiff-Bases. Bulletin of the Chemical Society of Ethiopia, 22, 219-224. https://doi.org/10.4314/bcse.v22i2.61288

[41] Matovic, Z.D., Miletic, V.D., Samardzic, G., et al. (2005) Square-Planar Copper(II) Complexes with Tetradentate Amido-Carboxylate Ligands. Crystal Structure of $\mathrm{Na}_{2}[\mathrm{Cu}(\text { obap })]_{2} \cdot 2 \mathrm{H}_{2} \mathrm{O}$, Strain Analysis and Spectral Assignments of Complexes. Inorgnica Chimica Acta, 358, 3135-3144. https://doi.org/10.1016/j.ica.2005.04.025

[42] Isabirye, D., Mtunzi, F. and Aiyelabola, T. (2014) Synthesis and Structural Characterization of 2,3,7,8,12,13,17,18-Octakis(propyl), N,N,N',N'-tetramethylaminoporphyrazines and 2,3,9,10,16,17,23,24-octa Substituted Phthalocyanine and the Kinetic Studies of Their Co(II) and Cu(II) Metalated Complexes. Dyes and Pigments, 109, 214-222. https://doi.org/10.1016/j.dyepig.2014.05.013

[43] Ibrahim, M., Wang, F., Lou, M., Xie, G., Li, B., Bo, Z., Zhang, G., Liu, H. and Wareth, A. (2011) Copper as an Antibacterial Agent for Human Pathogenic Multidrug Resistant Burkholderia cepacia Complex Bacteria. Journal of Bioscience and Bioengineering, 112, 570-576. https://doi.org/10.1016/j.jbiosc.2011.08.017

[44] Claudel, M., Schwarbe, V. and Fromm, K.M. (2020) New Antimicrobial Strategies Based on Metal Complexes. Chemistry, 2, 849-899.

https://doi.org/10.3390/chemistry2040056

[45] Chohan, Z.H., Scozzafava, A. and Supuran, C.T. (2006) Synthesis of Biologically Active $\mathrm{Co}(\mathrm{II}), \mathrm{Cu}(\mathrm{II}), \mathrm{Ni}(\mathrm{II})$ and $\mathrm{Zn}(\mathrm{II})$ Complexes of Symmetrically 1,1'-Disubstituted Ferrocene Derived Compounds. Synthesis and Reactivity in Inorganic and Metal-Organic Chemistry, 33, 241-257. https://doi.org/10.1081/SIM-120017783

[46] Aiyelabola, T.O., Akinkunmi, E., Ojo, I., Obuotor, E., Adebajo, C. and Isabirye, D. (2017) Syntheses, Characterization, Resolution and Biological Studies of Coordination Compounds of Aspartic Acid and Glycine. Bioinorganic Chemistry and Appli- 
cations, 2017, Article ID: 2956145. https://doi.org/10.1155/2017/2956145

[47] Chohan, Z.H., Farooq, M.A., Scozzafava, A. and Supuran, C.T. (2002) Antibacterial Schiff Bases of Oxalyl-Hydrazine; Diamide Incorporating Pyrrolyl and Salicylyl Moieties and of Their Zinc(II). Journal of Enzyme Inhibition and Medicinal Chemistry, 17, 1-7. https://doi.org/10.1080/14756360290005598

[48] Stanila, A., Marcu, A., Rusu, D., Rusu, M. and David, L. (2007) Spectroscopic Studies of Some Copper(II) Complexes with Amino Acids. Journal of Molecular Structure, 834-836, 364-368. https://doi.org/10.1016/j.molstruc.2006.11.048

[49] Worthington, P., Hambright, P., Williams, R., et al. (1980) Reduction Potentials of Seventy-Five Free Base Porphyrin Molecules: Reactivity Correlations and the Prediction of Potentials. Journal of Inorganic Biochemistry, 12, 281-291.

https://doi.org/10.1016/S0162-0134(00)80269-X

[50] Inamo, M., Kamiya, N., Inada, Y., et al. (2001) Structural Characterization and Formation Kinetics of Sitting-Atop (SAT) Complexes of Some Porphyrins with Copper(II) Ion in Aqueous Acetonitrile Relevant to Porphyrin Metalation Mechanism. Structures of Aquacopper(II) and Cu(II)-SAT Complexes as Determined by XAFS Spectroscopy. Inorganic Chemistry, 40, 5636-5644.

https://doi.org/10.1021/ic010162b 